\title{
LAS INTRIGAS POLÍTICAS DE JUAN PACHECO. DEL COMBATE DE OLMEDO A LA MUERTE DE JUAN II $(1445-1454)$
}

\author{
THE POLITICAL PLOTS OF JUAN PACHECO. \\ FROM OLMEDO'S COMBAT TO JOHN II'S DEATH \\ (1445-1454)
}

\section{ALFONSO FRANCO SILVA Universidad de Cádiz}

\begin{abstract}
Resumen: En el trabajo que se ofrece a la consideración de los investigadores intento analizar la trayectoria política de Juan Pacheco, privado del Príncipe de Asturias, desde que merced a la privanza con don Enrique consiguiera el título y señorío de marqués de Villena en 1445 hasta la muerte de Juan II en 1454.
\end{abstract}

Palabras clave: Juan Pacheco; Marquesado de Villena; Reino de Castilla; Siglo $\mathrm{XV}$.

\begin{abstract}
In this essay, offered to the consideration of researchers, I try to analyse the political evolution of Juan Pacheco, royal favourite of Principe de Asturias, since thanks to the favour with Don Enrique he got the title and domain of Marquis of Villena in 1445 until Juan II died in 1454.
\end{abstract}

Keywords: Juan Pacheco; Marquesado de Villena; Reino de Castilla; 15th century.

\section{SUMARIO}

1. De Olmedo al "golpe” de Záfraga (1445-1448).- 2. De Záfraga al final del reinado de Juan II.- Apéndice documental.

"Lo qual hazia (el principe), por inducimiento de Don Juan Pacheco, marqués de Villena, queriendo poner al rey en necesidades, porque con aquellas rescibiese mercedes é acrecentase su estado"(Crónicas de Juan II, "Biblioteca de Autores Españoles" (cap. IX, p. 652).

"La fama era que el Príncipe lo fazia por inducimiento de don Jhoan Pacheco, marqués de Villena, su criado, el qual se presume que lo fazía a fin de sacar del Rey algunos yntereses, según que lo avía acostumbrado, e asimismo por desviar al dicho condestable e maestre de Santiago de la corte; por que él así desviado, pudiese con el fabor del Prínçipe mandar en el rreyno más que otro alguno"(Crónica del Halconero de Juan II, Pedro Carrillo de Huete. Edición de Juan de Mata CARRIAZO, cap. CCCL, p. 478).

"E por quanto el señor Prínçipe se pagava mucho de los ginetes, más que de los omes de armas, e aqueste Rodrigo era manceuo de buen cuerpo, e cavalgava bien a la gineta, e lançava vien lança a cavallo, por lo qual el señor Príncipe tomó con él tanto amor, que los dichos maestre e marqués, con los celos que dello ovieron touieron manera de lo apartar del señor Prínçipe..... e en este comedio creçió el amor en el Prínçipe con el dicho Rodrigo Puertocarrero mucho más en ausencia que 
no en presençia" [aquí la crónica se interrumpe] (Crónica del Halconero de Juan II, cap. CCCLXXXV, p. 540).

\section{De OlMEdO AL “GOLPE” DE ZÁFRAGA (1445-1448)}

"Aumento en el número de linajes de la alta nobleza, conservación o enriquecimiento de los antiguos, tal es la realidad que se ofrece al día siguiente de Olmedo". Con estas precisas palabras el profesor Suárez Fernández describe la situación del reino de Castilla tras la derrota de los infantes de Aragón ${ }^{1}$. La victoria sobre los aragoneses en Olmedo no significó sólo el triunfo de don Álvaro de Luna sino también y, sobre todo, como veremos, el de la nobleza como grupo. Por de pronto, y por lo que respecta al personaje que nos ocupa, en los años posteriores a Olmedo tanto el nuevo marqués de Villena, como su hermano el flamante maestre de Calatrava, irán acrecentando sus dominios personales, consolidando su situación de nuevos ricos-hombres del reino y escalando posiciones de poder a la espera del momento supremo, que llegaría cuando su protector sucediese a su padre en la Corona de Castilla. Para conseguir estos objetivos, ambos hermanos, manejando a su conveniencia el poderoso instrumento que el destino les había proporcionado, se reparten los papeles e inician una época de tira y afloja, de pequeñas revueltas seguidas rápidamente de negociaciones, amenazas, alarmas, cabalgadas, levantamientos.... con la finalidad de acorralar al privado de Juan II, de tenerle más o menos maniatado, casi a su merced, para hacerse cada vez más necesarios e indispensables al poder, a fin de arrebatarle más y más donaciones de villas y rentas que le permitiesen a su vez incrementar sus posesiones. Hacerse cada vez más ricos para convertirse en más poderosos y llegar a controlar por completo la gobernación del Estado, como sugiere el halconero de Juan II en el segundo texto que sirve de pórtico a este trabajo. En este reparto de papeles, siempre, desde luego, unidos por una común ambición, se destaca sobremanera la figura de Juan Pacheco, un hombre extraordinariamente hábil, astuto e inteligente, dotado de cualidades políticas innegables para la intriga, el pacto y la seducción, sin importarle jamás la palabra dada, el juramento o la amistad. Nada le detenía si con ello podía satisfacer su apetito desordenado de poder, riqueza y dominio. Pacheco pensaba y trazaba el plan a seguir. Girón, hombre de acción, violento y brutal ejecutaba sus decisiones. Ambos hermanos tendrían pleno éxito porque, además de favorecerle la privanza y de aprovechar a su favor la difícil y compleja coyuntura política de mediados del siglo XV en que vivieron y actuaron, se complementaban perfectamente. Uno era el cerebro, el otro el brazo militar. Teniendo en cuenta estas condiciones, la fortuna estaba asegurada. Lo veremos inmediatamente.

Entre 1445 y 1448 Pacheco y Girón lograron crear un extenso heredamiento, a costa en buena parte de los infantes de Aragón y de sus

${ }^{1}$ Luis SuÁREZ FERNÁNDEZ, Nobleza y Monarquía, Valladolid, 1959, p. 123. 
partidarios. Antes de Olmedo, en las capitulaciones firmadas el 2 de septiembre de 1444 entre don Álvaro de Luna y Juan Pacheco, éste último pidió expresamente al primero que le diese solemne promesa de que le entregarían, como precio por su colaboración con el bando real, además de la villa de Villena, tres aldeas pertenecientes al alfoz de Badajoz: Villanueva de Barcarrota, Salvatierra y Salvaleón ${ }^{2}$. Los tres lugares habían sido previamente segregados de la jurisdicción del concejo pacense y fueron de inmediato convertidos en villas ${ }^{3}$. Badajoz se opuso a este amplio despojo de su alfoz y, en consecuencia, se resistió a entregar a Juan Pacheco los tres lugares que le querían arrebatar. No estaba sólo el concejo pacense en esta oposición, tras él se hallaba un poderoso personaje que detentaba un extenso señorío en esa zona del sur de Extremadura, en concreto, en torno a las villas de Nogales, Feria y Zafra. Me refiero a don Lorenzo Suárez de Figueroa, que, bajo el pretexto de defender los intereses de Badajoz, ciudad que, por otra parte y, desde hacía algún tiempo, estaba mediatizada por su familia, no estaba dispuesto a tolerar la presencia de un nuevo poder en una zona que consideraba suya. No en vano ya hacía tres generaciones que los Suárez de Figueroa estaban enraizados en el sur de la región extremeña, en la que habían creado, como ya he dicho, un poderoso dominio señorial a costa en gran parte de la propia ciudad de Badajoz ${ }^{4}$. De ninguna manera iban a permitir que un nuevo señor, y más aún cuando se trataba del ambicioso privado del príncipe, se instalase en una zona tan próxima a sus posesiones. El concejo de Badajoz y el señor de Feria se unieron para impedir que Pacheco tomase posesión de esos tres lugares. No hubo forma, por tanto, de hacerse con esta prebenda. Pacheco, a través del príncipe, recurrió al rey que, por una cédula fechada en Arévalo, el 25 de enero de 1445, procedió a ordenar al concejo de esa ciudad extremeña y al propio don Lorenzo Suárez de Figueroa que cumpliesen con su mandato y, en consecuencia, entregasen Barcarrota, Salvatierra y Salvaleón al privado de don Enrique ${ }^{5}$. El monarca, y tras él don Álvaro, temían que la oposición del concejo pacense, en complicidad con don Lorenzo, frustrasen sus planes, tan delicada y sutilmente trazados, de incorporar al príncipe de Asturias y a su entourage a la gran coalición que estaban formando para enfrentarse definitivamente con los aragoneses. Podía ocurrir, por consiguiente, que el acuerdo con don Enrique y Pacheco se viniese abajo, si éste último no conseguía su objetivo de penetrar en tierras de Badajoz. Aún así, no era tan fácil que Badajoz accediese a la pérdida de una parte tan sensible de su tierra.

\footnotetext{
${ }^{2}$ Una copia de la donación se recoge en el libro Noticia de todos los lugares de que se componen los estados de Villena, Castañeda y Aguilar, que se hallaba en la biblioteca de la Casa Ducal de Frías con el número 72 cuando esta se encontraba depositada en el castillo del pueblecito cordobés de Montemayor.

${ }_{3}^{3}$ Ibídem. La enajenación de esos tres pueblos del alfoz de Badajoz la mandó hacer Juan II por cédula fechada el 13 de agosto de 1444 .

${ }^{4}$ Véase al respecto sobre este tema las documentadas páginas que le dedica en su Tesis Doctoral José Luis del PINO GARCÍA, Extremadura en las luchas políticas del siglo XV, Badajoz, Diputación Provincial, 1991, pp. 187-188.

${ }^{5}$ Noticia de todos los lugares de que se componen los estados de Villena, Castañeda y Aguilar, Casa Ducal de Frías, $n^{\circ} 72$.
} 
El propio monarca, ante la decidida resistencia del concejo pacense, tuvo que desplazarse a Extremadura y obligar a la ciudad a entregar a don Juan Pacheco por la fuerza los tres lugares mencionados, "de lo qual, como afirma el cronista de Juan II, mucho pesó a los de Badajoz, e pusieron en ello muchas excusas, pero a la fin ovieron de obedecer el mandamiento del rey" ${ }^{\prime 6}$. La toma de posesión efectiva no tendría lugar, sin embargo, hasta después de la derrota de los infantes en Olmedo. Fue, en efecto, este triunfo, y los graves sucesos que se desencadenaron inmediatamente después, como veremos, los determinantes de la incorporación de estos tres lugares a los dominios de Juan Pacheco. En cualquier caso, había que preguntarse qué interés podía tener el intrigante privado del príncipe por hacerse con ese territorio extremeño que hasta ese momento no parecía formar parte de sus planes. Si resulta fácilmente explicable su deseo de apoderarse de Villena y, en consecuencia, reconstruir para su propio beneficio el antiguo marquesado, a pesar de que en principio no se presentaba como una tarea sencilla, en cambio la pretensión de incorporar a su patrimonio esas nuevas villas extremeñas no parece tener una respuesta razonable, a no ser que pensase crear en esa zona un extenso heredamiento que le permitiese hacerse algún día con el control de la ciudad de Badajoz. Es muy probable que esta última sea la explicación lógica a ese interés, ciertamente novedoso, que manifiesta por las tierras del sur de la región extremeña, probablemente también por la proximidad de esas tres villas, sobre todo Bancarrota, a Villanueva del Fresno, señorío este último que acababa de conseguir por su matrimonio con María Portocarrero. Es posible conjeturar también que en los planes de Pacheco, esas tres pueblas extremeñas podían servir y ser utilizadas como moneda de cambio, tal como ya hemos señalado en otra ocasión, para hacerse con otros señoríos que le interesaban más. De todas maneras el resultado de este complicado proceso sería la incorporación a su patrimonio de nuevos dominios.

No sería la última vez que Pacheco se interesase por la región extremeña. Pronto le veremos entrar en posesión de otra villa, Medellín, y al final de su vida, pocas horas antes de morir, se apoderará de Trujillo, la última de sus codiciadas y numerosas presas.

No fue de extrañar, sin embargo, que pocos días después del combate de Olmedo, y como primer fruto de su activa colaboración en la derrota de los infantes, recibiese Jumilla, una villa que había formado parte del antiguo marquesado de Villena. La donación de Jumilla era consecuencia directa de la concesión de Villena. Pacheco la pidió expresamente al príncipe como parte del botín que tramaba conseguir por su intervención en Olmedo y el pacto con el condestable. Don Enrique se apresuró a solicitar a su padre la donación de esa villa a Pacheco, y el rey no tuvo más remedio que emitir un albalá desde Portillo por el que donaba Jumilla al servidor del príncipe por los servicios prestados a su hijo "e porque vuestra casa e estado sea más acrescentado porque quanto más acresçentado fuere vos me podades más e en mayor grado

${ }^{6}$ Crónica de Juan II, cap. XXII, p. 637. 
seruir, e porque de vos e de vuestros seruiçios quede mayor memoria" ${ }^{7}$. El monarca se reservaba, como siempre, las alcabalas, los mineros de oro, la superioridad de la justicia y, en este caso concreto, la aduana del puerto. Al contrario que en el caso de las villas extremeñas, nadie podía sentirse sorprendido, después de la donación de Villena, de que Pacheco aspirase a incorporar Jumilla a sus dominios, todo lo más podría parecer una nueva osadía del privado del príncipe. Y, sin embargo, de manera muy parecida a lo que había sucedido con las villas extremeñas, tampoco le sería fácil a Pacheco tomar posesión de Jumilla. Esta vez no fue un concejo de realengo quien se oponía a la entrega, sino un poder de envergadura en el reino de Murcia, aunque discutido por esta época, nada menos que doña María de Quesada, madre y tutora del adelantado de ese reino, Pedro Fajardo, aún de menor edad ${ }^{8}$. La viuda de Alfonso Yáñez Fajardo, que estaba llevando a cabo una defensa tenaz y ejemplar de los dominios de su hijo, opuso una dura resistencia a esa donación, entre otras razones porque Jumilla era una promesa que el rey había hecho a su hijo, e incluso había habido de por medio una donación por escrito de esa villa ${ }^{9}$. En efecto, Jumilla iba a constituir el premio que el adelantado y su madre recibirían por la decidida defensa que de los intereses de la monarquía habían llevado a cabo en el reino de Murcia frente a los partidarios de los infantes de Aragón. Para complicar aún más la situación, el propio concejo de Jumilla se opuso a ser enajenado en señorío, con el argumento de que la Corona le había hecho solemne promesa de no separarla jamás del realengo. Ante esta situación, Juan II se vio obligado a dar marcha atrás y decidió paralizar la entrega de la villa a Pacheco, pero no lo hizo por la oposición del concejo de Jumilla sino para evitar la posible desafección de la madre del adelantado. Así pues, la villa no se podía conceder a Pacheco, pero tampoco podía entregarse a doña María de Quesada, porque a esto último se oponía decididamente el príncipe de Asturias. Al final, padre e hijo determinaron entregar Jumilla en secuestro al prior de San Juan, fray Gonzalo de Quiroga, que la mantendría bajo su custodia hasta que una comisión de juristas dictaminase a quién había que concederla. Pacheco no tuvo más remedio que esperar hasta el año 1451 para que la merced de la villa se hiciese efectiva. Se llegó por entonces a la conclusión de que la donación a Pacheco se había hecho bastante antes que al adelantado y, en consecuencia, el monarca le donó la villa por un albalá fechado en Torrijos el 22 de marzo de $1451^{10}$. La cédula real de concesión de Jumilla le fue entregada a un hombre de confianza del privado del príncipe, el obispo de Ávila, don Alfonso

${ }^{7}$ Archivo Ducal de Frías (en adelante $A D F$ ), Caja 2, no 20 . Advierto de antemano que sigo la catalogación de Pilar LEON TELLO, Inventario del Archivo de los duques de Frías, tomo II, Casa de Pacheco, Madrid, 1973.

${ }^{8} \mathrm{La}$ información procede del libro Noticia de todos los lugares de que se componen los estados de Villena, Castañeda y Aguilar, Biblioteca de la Casa Ducal de Frías, $n^{\circ} 72$.

${ }^{9}$ Sobre los Fajardo véase el trabajo de Juan TORRES FONTES, Los Fajardo en los siglos XIV y XV, Miscelánea Medieval Murciana”, 1978 en especial pp. 178-179 y mi libro El marquesado de los Vélez (siglos XIV-mediados del XVI), Murcia, Academia Alfonso X el Sabio, p. 38.

${ }^{10}$ Noticia de todos los lugares de que se componen..... 
de Fonseca, que había sido capellán mayor de la Casa de don Enrique ${ }^{11}$. El purpurado la hizo llegar a su destinatario, mientras que el rey por su parte, en otra cédula fechada el 27 de junio de 1452, ordenaba al prior de San Juan que entregase la villa al marqués de Villena. Al año siguiente, desde Tordesillas, Juan II otorgaba privilegio solemne de donación de Jumilla a Juan Pacheco ${ }^{12}$. Pacheco había tardado, por tanto, casi siete años en hacerse con esta villa. Aún así, aunque fuese a trancas y a barrancas, con oposición o sin ella, iba consiguiendo todo lo que se había propuesto. La mejor jugada, sin embargo, vendría a continuación.

Acabo de afirmar, no ha mucho, que Olmedo significó, más que el triunfo de don Álvaro, el de toda la nobleza como grupo. Esta es la conclusión a la que llegó el profesor Suárez Fernández hace ya algunos años ${ }^{13}$. Y no se equivocaba desde luego porque los hechos que siguen le dan plenamente la razón. En efecto, pasada la alegría de la primera hora, tras la victoria sobre los infantes, surgirían desavenencias entre los vencedores, y en concreto entre el príncipe de Asturias y don Álvaro. Transcurridos unos cuantos días después de la batalla, el príncipe don Enrique, aconsejado por Pacheco, emprende "secretamente" la huída del campamento real instalado en Simancas y se refugia en Segovia como ya había hecho en varias ocasiones anteriores ${ }^{14}$. Procedió entonces a pactar un acuerdo con el almirante don Fadrique, prometiéndole tanto a él como a su hermano don Enrique y a Juan de Tovar que le serían devueltos todos sus bienes "e tornados en todo su honor" ${ }^{15}$. Para volver a la corte, don Enrique exigió después a su padre que no se le embargaran los señoríos del almirante, aunque éste hubiese combatido en Olmedo junto a los infantes, y que se le hiciera entrega efectiva para su propio patrimonio de las ciudades de Jaén, Logroño, Ciudad Rodrigo y Cáceres, así como las tres villas extremeñas ya mencionadas para Juan Pacheco de las que aún no había tomado posesión ${ }^{16}$. La segunda de estas demandas, instigada directamente por Pacheco, pretendía, según Suárez Fernández, crear para el heredero del trono "un dominio extenso, rico y potente que equilibrara las fuerzas de don Álvaro" ${ }^{17}$. Cuando Juan II se entera de la fuga de su hijo,

\footnotetext{
${ }^{11}$ Sobre Fonseca véase mi trabajo El Arzobispo Alonso de Fonseca el Viejo. Notas sobre su vida, "Boletín de la Real Academia de la Historia", CXCVI/1 (1999), Cuaderno I, pp. 43-92.

${ }^{12} \mathrm{El}$ documento se inserta en el que cito en la nota $\mathrm{n}^{0} 7$.

${ }^{13}$ Luis SUÁREZ FERNÁNDEZ, Nobleza y Monarquía, p. 123 y ss.

${ }^{14}$ Ibídem, Los Trastámaras de Castilla y Aragón en el siglo XV en Historia de España dirigida por D. Ramón MENÉNDEZ PIDAL, Tomo XV, Madrid, 1982, p. 187. Marcharon en primer lugar a santa María de Nieva y de allí a Segovia. Al parecer Pedro Girón no pudo huir porque estaba "durmiendo la siesta", y fue hecho prisionero por el rey. Véase a este respecto
Crónica de Juan II, cap. XI, pp. 630-631.

${ }^{15} \mathrm{ADF}$, Catálogo Antiguo, Leg. 56, $\mathrm{n}^{\mathrm{0}}$ 6. La cédula del príncipe al almirante va firmada en Urueña el' 20 de junio de 1445 .

${ }^{16}$ Sólo se reconciliarían con el rey si éste cumplía esas condiciones. Crónica de Juan II, cap. XI, p. 631.

${ }^{17}$ Luis SUÁREZ FERNÁNDEZ, Los Trastámaras, p. 188 y Enrique IV, Editorial Ariel, Barcelona, 2001. Tras la reconciliación del rey con su hijo, Pedro Girón quedó al frente de la fortaleza de Segovia. Don Enrique ordenó al concejo de Segovia "que todos hiciesen lo que Pero Girón mandase", Crónica de Juan II, cap. XII, p. 632.
} 
mostró una enorme indignación pues, como afirma el cronista "aquel movimiento del Príncipe no se había hecho con su consejo, ante le había pesado" ${ }^{18}$. Muy pronto, sin embargo, aconsejado por su privado, no tuvo otra opción que plegarse a sus deseos. El condestable, por su parte, no le quedó más remedio que pactar de nuevo con el promotor de la huida, que no era otro que Pacheco que le exigió, a cambio de la reconciliación con el heredero, nuevas mercedes para sí y el perdón para todos los nobles que habían combatido al lado de los infantes. Así se haría, como veremos, desarmando por completo, como afirma el profesor Luis Suárez, los proyectos políticos de don Álvaro ${ }^{19}$. Al condestable, por consiguiente, tras la victoria de Olmedo, sólo le quedaban dos opciones: pactar con los nobles, en especial con Juan Pacheco, o el recurso a la fuerza que, desde el golpe de Rámaga de 1443 perpetrado por el rey de Navarra, no era nada aconsejable. Don Álvaro se vio obligado a recurrir al primer procedimiento; así se explican las vistas de San Martín de Valdeiglesias y el acuerdo de Astudillo celebrado en 1446. En San Martín hubo una reconciliación entre padre e hijo el 3 de septiembre de 1445. Previamente, cuando aún se hallaba en el real de Juarros de Voltoya, el monarca se había comprometido a respetar la persona y estados de su hijo, así como también las de sus dos consejeros, Pacheco y Girón ${ }^{20}$. Recibían una carta de seguro real en la que Juan II les daba palabra solemne de que no serían puestos en prisión ni embargados sus bienes "e que podais venir a mi corte cuando lo querais y tornar donde quisierdes". Aún así, a pesar de la solemne promesa real, Pacheco no se fiaba del condestable, y en consecuencia aconsejó entonces al príncipe que esa carta de seguro fuese firmada por el propio don Álvaro y por los condes de Haro y de Alba, así como por el maestre de Alcántara, don Iñigo López de Mendoza, don Alfonso de Fonseca, obispo de Ávila y el contador Alfonso Pérez de Vivero. A esa cédula de seguro le siguió un pacto en toda regla firmado en San Martín el 2 de septiembre de ese mismo año ${ }^{21}$. En virtud de ese acuerdo, Juan II y don Álvaro, de una parte, y el príncipe y Pacheco por otra se comprometían a cumplir toda una serie de capítulos:

a) El maestrazgo de Santiago quedaría para el condestable y el de Calatrava pasaría a poder de Pedro Girón.

b) La ciudad de Jaén le sería entregada al príncipe de Asturias en un plazo no superior a los tres meses.

c) El rey enviaría a una persona con órdenes estrictas al concejo de Cáceres para que la villa se redujese a la obediencia del príncipe. Al enviado real le acompañaría otra persona de la confianza de don Enrique para proceder a la entrega. El mismo procedimiento se haría con respecto a los tres lugares que Pacheco debería recibir en tierras de Badajoz. En cualquier caso, si la

\footnotetext{
${ }^{18}$ Crónica de Juan II, cap. XI, p. 631.

${ }^{19}$ Luis SuÁREZ FERnÁNDEZ, Los Trastámaras, p. 188.

${ }^{20}$ ADF, Catálogo Antiguo, Leg. 56, sin foliar.

${ }^{21} \mathrm{ADF}$, Catálogo Antiguo, Leg. 56, n ${ }^{\circ} 6$.
} 
resistencia del concejo pacense continuaba, sería el propio rey quien se desplazaría a la ciudad para asegurar la entrega, como así efectivamente sucedería según hemos expuesto antes. El plazo para ambas cesiones se fijó en setenta días.

d) La compensación que recibiría Pacheco por la renuncia a la villa de Ágreda se haría efectiva, en presencia del propio beneficiado y de don Álvaro, en un plazo no superior a los quince días.

e) Se ratificaría la amistad y confederación entre el condestable y Pacheco. A fin de que fuese efectivo y seguro, el pacto entre ambos magnates ser haría en presencia del obispo de Cuenca, del alférez mayor, de Alfonso Pérez de Vivero y de Alfonso Álvarez.

f) Doña Juana Enríquez, esposa del rey de Navarra, quedaría como rehén en poder de una persona que fuese "honesta y lo más neutral que se pudiere aver, e que la tenga con vna dueña o dos que fuere acordado allende de las mugeres del seruiçio que ella acostunbra a tener". La persona a quien se le confiase su custodia no podía ni trasladarla a otro lugar ni mucho menos entregarla sin la licencia del monarca y del príncipe, y el acuerdo del condestable y Pacheco.

g) El almirante y el conde de Benavente, pasado un cierto tiempo, dejarían de ser "arrehenes", quedarían en libertad y se les devolverían sus fortalezas y bienes. La esposa del rey de Navarra quedaría después en poder de su padre, el almirante, siempre que éste último prometiese dar toda clase de seguridades de que no la entregaría a su esposo sin licencia expresa de Juan II y de su hijo. Al almirante se le permitiría marchar de Segovia, donde se hallaba protegido por el príncipe, a la villa de Pedraza de la Sierra, en la que permanecería no más allá de cinco días. El conde de Benavente, por su parte, otro partidario de los infantes, podía marchar libremente a cualquier villa de sus estados. De la misma forma se procedería con el conde de Plasencia. A todos ellos se les daría carta real de seguro para poder desplazarse libremente.

h) El condestable y Pacheco quedarían obligados a firmar un pacto de confederación con todos los grandes del reino.

i) Se aprobaban y confirmaban los acuerdos a los que habían llegado el rey y el príncipe en Torrelobatón: el primero tomaría en prendas una fortaleza del almirante y el segundo otra del conde de Benavente.

Tras la firma de este pacto, tanto Juan II como su privado pensaban en haberse ganado la voluntad y confianza del príncipe de Asturias. De nuevo se equivocaban, pronto Pacheco les convencería de lo contrario. El acuerdo entre padre e hijo, sin embargo, resultaba muy beneficioso para este último y, sobre todo, para sus dos predilectos servidores. De entrada, dos personajes que habían sido vencidos en Olmedo, el almirante y el conde de Benavente, recuperaban su libertad y sus respectivos patrimonios. Y lo que era aún más significativo, al príncipe se le prometían Jaén y Cáceres, a Pacheco las villas extremeñas y una fuerte compensación por la pérdida de la villa de Ágreda, y a Girón, finalmente, se le hacía maestre de la orden de Calatrava. Vamos a ver a continuación, de una manera más detallada, cómo éstos dos últimos salieron muy beneficiados del pacto de San Martín. 
Al día siguiente de firmarse el acuerdo, Pacheco recibió por su manifiesta colaboración la primera de las muchas prebendas que acaparará entre el pacto de San Martín y los acuerdos de Astudillo del año 1446. En efecto, el 3 de septiembre de 1445 Juan II concedía de por vida a su padre, Alonso Téllez Girón, la villa de Almansa, con la condición que tras su muerte pasase a poder de su hijo ${ }^{22}$. Por aquel entonces, don Alonso desempeñaba el oficio de mariscal del príncipe de Asturias y gobernaba los señoríos que hasta entonces había recibido su hijo Juan ${ }^{23}$. Este, por su parte, desde hacía algún tiempo había puesto los ojos sobre Almansa, villa ésta que juzgaba importante para sus planes de incorporación del antiguo marquesado de Villena. No podía, sin embargo, hacerse con esa villa porque se hallaba bajo la jurisdicción del conde de Castro, Diego Gómez de Sandoval. Este personaje, al que he dedicado cierta atención en un trabajo anterior, era uno de los hombres de la máxima confianza del rey Juan de Navarra porque se había criado y promocionado en la Casa de su padre, el infante - luego rey de Aragón-don Fernando de Antequera ${ }^{24}$. Precisamente la donación de Almansa, concedida por Juan II bajo la presión de Juan de Navarra -que controlaba desde 1439 algunas villas del antiguo marquesado tras los acuerdos matrimoniales de su hija Blanca con el príncipe Enrique-, constituía una pieza importante para el control por parte de los aragoneses de un territorio tan sensible y tan cercano a la frontera con el reino de Valencia como era el antiguo estado de Villena. De aquí la presencia del conde de Castro en esa zona, sin duda una garantía para los intereses de Juan de Navarra. Como ya sabemos, los planes de los aragoneses para controlar el reino de Castilla se vinieron abajo tras la batalla de Olmedo. Fue entonces cuando Pacheco vio llegada la hora de apoderarse de Almansa, que le había sido confiscada al conde de Castro tras la derrota. Consigue, pues, que la villa se le conceda a su padre, siempre desde luego que después de la muerte de éste pasase a su poder.

Los despojos de los vencidos se repartían, como siempre había sucedido en Castilla, entre los vencedores. Pacheco consigue Almansa como botín de guerra a costa del despojo del patrimonio del conde de Castro. Pero no sólo será Almansa, también llegará a recibir Lerma, otra de las villas importantes pertenecientes a la jurisdicción de Diego Gómez de Sandoval ${ }^{25}$. En efecto, unos días más tarde, el 13 de septiembre desde San Martín de Valdeiglesias, el monarca, a petición del propio Pacheco, le concederá Lerma, villa de la que tomaría posesión en su nombre el 23 de octubre de ese año,

${ }^{22} \mathrm{ADF}$, Catálogo Antiguo, Leg. 56, no 10.

${ }^{23}$ Ver a este respecto sobre el nombramiento de mariscal el documento $\mathrm{n}^{\mathrm{o}} 10$ del $A D F$, Catálogo Antiguo, Leg. 56, $\mathrm{n}^{\circ} 10$. En 1441 en nombre de su hijo había nombrado alcalde de la fortaleza de Munera a Pedro Rodríguez Noguerol. Este último documento en $A D F$, Catálogo Antiguo, Leg. 56, sin foliar.

${ }^{24}$ Alfonso FRANCO SILVA, El linaje Sandoval y el señorio de Lerma en el siglo XV, trabajo recogido en el libro Señores y Señorios, Servicio de Publicaciones de la Universidad de Jaén,

${ }^{25}$ ADF, Caja 2, no 21. 
Andrés de Frías, repostero mayor del príncipe Enrique ${ }^{26}$. La justificación de la donación ya la conocemos: el conde de Castro había sido derrotado junto con los infantes, sus protectores, en Olmedo y, en consecuencia, había sido despojado de todas sus villas y rentas.

Es indudable que el interés que Pacheco mostraba hacia Almansa estaba plenamente justificado, y ya lo hemos hecho notar antes. Lo que no parece tener una explicación lógica es la posesión de Lerma, a no ser que pensemos en la extrema ambición del personaje que le llevaba a acaparar toda clase de señoríos, estuviesen donde fuese, muy alejados de la zona de mayor interés - la Mancha y el marquesado- o muy próximos; el caso era incorporar una villa tras otra, una renta detrás de otra. Es posible que ésta sea la causa que explique la incorporación de Lerma, una villa situada en territorio burgalés, muy alejada por tanto de la zona que hasta ahora parecía concentrar toda la atención de Pacheco. También como ya he afirmado antes, Lerma, como otras villas que entraban en su patrimonio, podía ser utilizada como moneda de cambio, e incluso como pieza política de importancia si se quería conseguir algo que interesara más.

La confiscación del patrimonio del conde de Castro había beneficiado particularmente a Pacheco que, como hemos visto, se hizo con dos de sus villas, Almansa y Lerma. Pero otros más poderosos que Sandoval también perdieron en Olmedo. En primer lugar, y tras Juan de Navarra, su hermano el infante don Enrique, maestre de Santiago. El despojo de los bienes de éste personaje, que murió poco después de la batalla, se repartieron entre don Álvaro y Juan Pacheco. El primero se hizo con el maestrazgo de Santiago y los señoríos de Alburquerque y La Codosera ${ }^{27}$. Al segundo le correspondió Medellín, que le fue concedida por cédula real fechada también el 13 de septiembre, día en que se le había hecho merced de Lerma ${ }^{28}$. Pacheco recibía Medellín con sus aldeas de Don Benito, Santisteban, Cristina, Guareña, Martín Gabriel, Valdetorres, Don Llorente, El Villar, Juan Sancho, Miajadas y el lugar de Don Salvador, que por entonces estaba despoblado comprometiéndose Pacheco a repoblarlo ${ }^{29}$.

El nuevo marqués de Villena no olvidaría jamás a lo largo de su azarosa y ajetreada vida esa fecha, 13 de septiembre de 1445 . Un día antes había conseguido la dignidad de marqués de Villena, por la que venía luchando desde hacía seis años, pero jamás alcanzaría después tantos honores

\footnotetext{
${ }^{26} \mathrm{ADF}$, Caja 2, ${ }^{\circ} 23$.

${ }^{27}$ José Luis del PINO GARCíA, Extremadura en las luchas políticas del siglo XV, Diputación Provincial de Badajoz, 1991, p. 188.

${ }^{28}$ Ibídem. La donación de Medellín en Catálogo antiguo, Leg. $3, n^{\circ}$ 28. La toma de posesión de la villa se hizo el 11 de enero de 1444 . Véase a este respecto Emilio CABRERA MUÑOZ, Beatriz Pacheco y los orígenes del condado de Medellín, "Anuario de Estudios Medievales", 15 (1985), p. 515 y ss.

${ }^{29}$ No parece que Don Salvador llegara a repoblarse de acuerdo con lo que afirma Emilio CABRERA, art. cit., pp. 540-541; la toma de posesión en pp. 515 y ss.
} 
y beneficios como los que se le dieron en ese día ${ }^{30}$. Acabamos de ver cómo el 13 de septiembre recibía Lerma y Medellín. Pero es que además en ese día conseguía también que se le entregase en secuestro el oficio de Adelantado Mayor de Castilla que hasta Olmedo había ejercido el primogénito del conde de Castro, don Fernando de Sandoval y Rojas, y que le fue confiscado por el monarca tras la derrota, y puesto en poder de Juan Pacheco para que se beneficiase de las rentas que tal dignidad llevaba anejas ${ }^{31}$. Aún hay más: el 13 de septiembre en compensación por la pérdida de Ágreda recibe Villena, Sax, Yecla y varias aldeas de la tierra de Alarcón, en total 1.000 vasallos $^{32}$. Entre esas aldeas de Alarcón se encontraba Hontanaya, que tenía en aquel momento diecinueve vasallos, de la que tomó posesión en su nombre el bachiller Mateo Fernández de Medina del Campo, juez comisionado por Juan II para entregar los 1.000 vasallos prometidos en las villas mencionadas ${ }^{33}$. Hontanaya fue cedida a Pacheco por una cédula del príncipe Enrique, fechada en Almagro unos días más tarde, el 24 de septiembre de $1445^{34}$. De inmediato, Pacheco envió a esa aldea, que fue segregada de Alarcón y agregada al señorío familiar de Belmonte el 25 de octubre de ese año, a su criado Gonzalo de Soto que hizo poner una horca - símbolo de la jurisdicción señorial- entre dos caminos que iban de Hontanaya a Almonacid, nombró después dos alcaldes, un alguacil y dos regidores para terminar finalmente con el amojonamiento y delimitación del término ${ }^{35}$.

Entre los días 12 y 13 de septiembre Juan Pacheco había incorporado a sus dominios, además de Lerma, Medellín y la dignidad de Adelantado Mayor del reino de Castilla, una serie de villas por las que tenía extraordinario interés desde hacía años, Villena, Sax y Yecla, además del título de marqués de esa antigua demarcación territorial. De esta manera, al haber conseguido ya Utiel, Jumilla y Almansa, estaba en las mejores condiciones posibles para hacerse con todos los demás pueblos que habían formado parte del marquesado y que, como veremos más adelante, no tardarían en caer bajo su poder. De la noche a la mañana, en poco más de cinco años, había pasado de ser un doncel sin fortuna, heredero de un señorío tan modesto como Belmonte, a crear un extenso y sólido dominio en la Mancha oriental. Villena, Sax y Yecla habían formado parte, como he dicho antes, del marquesado de

${ }^{30}$ La concesión del título de marqués en ADF, Catálogo Antiguo, Leg. 31, n ${ }^{\circ}$ 5. Lo he publicado íntegro en Las primeras ordenanzas municipales de Villena en Estudios sobre Ordenanzas Municipales (siglos XIV-XVI), Servicio de Publicaciones de la Universidad de Cádiz, 1998, pp. 66-67.

${ }^{31}$ ADF, Catálogo Antiguo, Leg. 3, no 17. Don Fernando era hijo primogénito del conde de Castro. Véase a este respecto Ȧlfonso Franco Silva, Señores y Señoríos, p. 100.

${ }^{32} \mathrm{ADF}$, Catálogo Antiguo, Leg. 3, no 18. Véase al respecto mi trabajo Las primeras ordenanzas municipales de Villena (1440-1445) en Estudios sobre Ordenanzas Municipales, pp. 48-50.

${ }^{33}$ Documento recogido en el libro Noticia de todos los lugares de que se componen los Estados de Villena, Castañeda y Aguilar. La enajenación de Hontanaya de la villa de Âlarcón en ADF, Catálogo Antiguo, Leg. 3, n ${ }^{\circ} 25$.

${ }^{34}$ Ibidem.
${ }^{35}$ Ibidem. 
Villena que, por entonces, y como ya sabemos, pertenecía a los dominios del príncipe de Asturias. Don Enrique cedió muy gustoso a su hombre de confianza esas tres villas que desde algún tiempo venía pidiéndole, pero exigió a su padre una compensación por su renuncia. Juan II se vio obligado entonces a donarle, en ese mismo día trece de septiembre, y en equivalencia de Ágreda, las ciudades de Calahorra y Nájera ${ }^{36}$. De esta misma manera, el heredero del trono no veía disminuir su patrimonio por las injerencias sucesivas y continuas de su privado. Este último, por su parte, se dio mucha prisa en tomar posesión de Villena, Sax y Yecla y también por obtener nueva confirmación, si se presentaba alguna contrariedad, de sus antiguas posesiones de Utiel, Villanueva de Alcaraz, El Bonillo y Munera ${ }^{37}$.

Todas estas concesiones habían sido el precio que había impuesto Pacheco a Juan II y a don Álvaro de Luna si querían que el príncipe Enrique retornase a la obediencia real. Cualquier procedimiento le parecía bueno si le podía permitir no sólo acercarse cada vez más al poder real, sino también, y sobre todo, conseguir la donación de nuevas villas, lugares y tierras. Y para su hermano, Pedro Girón, la gran prebenda del maestrazgo de Calatrava.

La reconciliación de San Martín entre padre e hijo fue más aparente que real. Muy pronto, Pacheco volverá a utilizar nuevos pretextos para enemistar a don Enrique con Juan II. Y de esa manera conseguir más beneficios para sí y para su hermano. En efecto, las desavenencias surgieron pocos meses después de las vistas de San Martín. La ocasión para la ruptura se la presentó el propio monarca cuando, tras su regreso de Extremadura, llegó a Toledo y allí procedió a destituir a Pero López de Ayala, un partidario decidido del príncipe de Asturias, como teniente del alcázar y de las fortalezas de esa ciudad ${ }^{38}$. El enojo del príncipe fue mayúsculo hasta el extremo de que se decidió a firmar una hueste, a la que se unieron tropas del almirante don Fadrique, los condes de Benavente y Plasencia, Juan de Tovar y Pedro Quiñones, es decir de todos los que habían sido represaliados después de Olmedo y se hallaban bajo la directa protección de don Enrique ${ }^{39}$. El heredero había dado a entender a estos nobles que había que hacer frente a la nueva tiranía que don Álvaro de Luna estaba ejerciendo en el reino, y que sólo él, por consiguiente, era el culpable de la destitución de los oficios que don Pedro López de Ayala detentaba en Toledo por su mandato ${ }^{40}$. En palabras del príncipe, recogidas por el halconero de Juan II, con esta acción don Álvaro trataba de "se apoderar en el reyno e desheredar los cavalleros naturales del rreyno" ${ }^{11}$. Parecía que se iba a producir un choque armado entre padre e hijo,

\footnotetext{
${ }^{36} \mathrm{ADF}$, Catálogo Antiguo, Leg. 3, no 19.

${ }^{37}$ Ibídem, $\mathrm{n}^{\mathrm{0}} 26$.

${ }^{38}$ Crónica de Juan II, cap. XXVI, p. 639; Crónica del Halconero de Juan II, cap. CCCXLII, p. 469 y Luis SUÁREZ FERNÁNDEZ, Los Trastámaras, pp. 189-190.

${ }^{39}$ Crónica del Halconero de Juan II, cap. CCCXLII, p. 469 y Luis SUÁREZ FERNÁNDEZ, Los Trastámaras, p. 190.

${ }^{40}$ Ibídem.

${ }^{41}$ Ibídem.
} 
pero al final ambos bandos llegaron a un trato ${ }^{42}$. Se impuso de nuevo una fórmula de compromiso en la que se nombró a don Álvaro de Luna, por la parte del monarca, y a Juan Pacheco por la del príncipe, a fin de que ambos tratasen de llegar a un acuerdo que resolviese las posibles diferencias que pudiesen existir entre ambos grupos ${ }^{43}$. Fue la llamada concordia de Astudillo, firmada en esa villa el 14 de mayo de 1446, y en la que se recogieron toda una larga serie de capítulos, que han sido convenientemente analizados por el profesor Suárez Fernández, utilizando para ello el texto completo del acuerdo que se reproduce íntegro en la crónica de Juan II $^{44}$. Astudillo no fue más que "un compás de espera" en palabras de Suárez "una nueva fórmula provisional de gobierno" que para nada beneficiaba al condestable Luna ${ }^{45}$. En todo caso quienes salieron ganando fueron Pacheco y Girón y, desde luego, también los nobles derrotados en Olmedo - el almirante, los condes de Castro y Benavente, Juan de Tovar y algún otro- que eran perdonados y restituidos en sus honores y bienes ${ }^{46}$. Se trató, así mismo, de buscar la mejor manera de administrar el reino, y se convino entonces en que había que devolver las funciones de gobierno al Consejo Real y que se encomendarían "el orden del servicio del rey y la ejecución de la justicia" a don Álvaro y al marqués de Villena ${ }^{47}$. Además de cierta participación en el gobierno del reino, a Juan Pacheco se le confirmaron todas las mercedes recibidas hasta ese momento ${ }^{48}$. Se habló también de ciertas enmiendas a satisfacer para los herederos del doctor Pero Yáñez por la pérdida de Villena, y de otras reparaciones para don Juan Ramírez de Guzmán por el maestrazgo de Calatrava que se confirmaba definitivamente a Pedro Girón ${ }^{49}$. Al príncipe de Asturias se le obligaba a devolver Arévalo, pero se le recompensaba con la importante fortaleza de Peñafiel, que pronto, como veremos, pasaría también a poder de Girón. Y poco más. Hubo sí un capítulo menor pero que afectaba muy directamente a Pacheco: el perdón y la devolución del patrimonio del conde de Castro, a quien jurídicamente le pertenecían dos villas que, tras Olmedo, habían pasado a poder del nuevo marqués de Villena. Me refiero naturalmente a Lerma y a

${ }^{42}$ Ibidem, cap. CCCXLV, p. 471 y ss.

${ }^{43}$ Ibídem, p. 472.

${ }^{44}$ Crónica de Juan II, 1446, cap. V, p. 641 y. ss. y Luis SUÁREZ FERnÁNDEZ, Los Trastámaras, p. 189 y ss. La concordia se recoge también en la Crónica del Halconero de Juan II, cap. CCCXLVI, p. 472 y ss.

${ }^{45}$ Luis SUÁREZ FERNÁNDEZ, Los Trastámaras, p. 189.

${ }^{46}$ Ibídem y Crónica del Halconero, cap. CCCXLVI, pp. 473 y ss.

${ }^{47}$ Ibídem, pp. 190-191.

${ }^{48}$ Aparecen recogidas en diversos documentos del ADF que por ser ya mencionadas no me ha parecido oportuno reproducirlas en esta nota. Se encuentran en los legajos números 4 y 46. Sí quiero advertir que una de las villas de las que ahora obtịene nueva confirmación es Yecla que, como Almansa, también había formado parte de los dominios del conde de Castro, Diego Gómez de Sandoval, y que igualmente había perdido como consecuencia de su participación en Olmedo. La toma de posesión de Yecla en nombre de Juan Pacheco la llevó a cabo Andrés de Frías el 23 de octubre de 1445, previo pleito-homenaje del alcalde de su fortaleza, Gómez García de Balboa; ADF, Caja $2, n^{\circ} 22$ y 23 .

${ }^{49}$ Crónica de Juan II, 1446, cap. V, p. 644. Véanse al respecto los documentos del ADF, Caja 6, números 7 y 8 . 
Almansa. En cuanto a la primera de esas villas un albalá de Juan II, fechado el 11 de junio de 1446, prometía a Villena que se le daría una compensación por renunciar a ella, y otra a don Álvaro de Luna porque también cedía el oficio de chanciller mayor de la Poridat (el sello secreto) que hasta su derrota había desempeñado el conde de Castro, y que tras el despojo de sus bienes había ido a parar a manos del condestable ${ }^{50}$. De Almansa, en cambio, no estaba dispuesto a desprenderse Pacheco bajo ningún concepto. Se le obligó, por tanto, al conde de Castro a renunciar a esa villa bajo promesa solemne de recibir más adelante una adecuada recompensa por su pérdida ${ }^{51}$. Es también por estas fechas cuando logra definitivamente recuperar Moguer para su esposa, María Portocarrero ${ }^{52}$. Girón, por su parte, vio confirmadas sus villas de Urueña, Tiedra y Pobladura, así como el maestrazgo de la orden de Calatrava.

El nuevo marqués de Villena podía sentirse íntimamente satisfecho de las ganancias recibidas antes y, sobre todo, después de Olmedo. No era así, sin embargo. Pronto puso sus ojos en otra villa manchega, Alarcón. No le iba a resultar difícil conseguirla porque Alarcón, como villa perteneciente al marquesado de Villena, se hallaba bajo la jurisdicción de su protector el príncipe Enrique. Pacheco quería apoderarse de la villa desde siempre, porque Alarcón, además de haber formado parte del antiguo marquesado, que pensaba reconstruir en su integridad una vez conseguido el título, se hallaba también próxima a sus dominios iniciales de Belmonte. Ya en 1429, su madre María Pacheco, de quién había heredado el señorío de Belmonte, había comprado a García Ruíz de Alarcón por 2.700 florines, una serie de heredades que formaban parte de la tierra de Alarcón ${ }^{53}$. Se trataba de Tres Juncos, Fuente Anaya, Fuentes y Villarejo de Fuentes. La misma Belmonte había formado parte como aldea del término de Alarcón hasta que fue creada villa por Pedro I, y entregada posteriormente al emigrado portugués Juan Fernández Pacheco, abuelo materno del privado del príncipe ${ }^{54}$. Las compras de 1429 venían a redondear el señorío de Belmonte pues las aldeas que poseía desde 1398, y que eran Robledillo, Las Pedroñeras, Las Mesas y Montalbarejo se ampliaban ahora con esas cuatro nuevas. De esta manera, el término de Alarcón, que había sido dotado de un extenso alfoz a raíz de su conquista en 1184, y del que formaban parte numerosas aldeas, contemplaba impasible su paulatina

\footnotetext{
${ }^{50}$ Esta información procede del libro Noticia de todos los lugares de que se componen..., citado en la nota $\mathrm{n}^{\mathrm{O}} 33$.

${ }^{51}$ La cesión de Almansa por Diego Gómez de Sandoval en el ADF, Catálogo Antiguo, Leg. $49, \mathrm{n}^{\circ} 4$

${ }^{52} \mathrm{ADF}$, Caja 2, sin foliar.

${ }^{53} \mathrm{ADF}$, Caja $100, \mathrm{n}^{\mathrm{0}} 5$.

${ }^{54}$ Alfonso FrANCO SILVA, Notas sobre la villa de Alarcón y su tierra en la Baja Edad Media recogido en el libro En la Baja Edad Media (Estudios sobre señoríos y otros aspectos de la sociedad castellana entre los siglos XIV al XVI), Servicio de Publicaciones de la Universidad de Jaén, 2000, pp. 428-429. Sobre los, orígenes portugueses de Juan Pacheco mi trabajo en colaboración con José Antonio GARCía LUJÁN, Los Pachecos. La imagen mítica de un linaje portugués, en tierras de Castilla, en "Actas de II Jornadas Luso-Espanholas de Historia Medieval", III, Porto, 1989, pp. 943-991.
} 
reducción. Albacete, San Clemente, Villanueva de la Jara, Las Pedroñeras, Las Mesas, Villarejo de Fuentes, Tres Juncos, Tarazona, Belmonte, Robledillo, Fuentes, Fuente Anaya, Ruz, Ferrera, Zancara, el Castillo de Garcí-Muñoz y algunas otras habían sido enajenadas de su término entre fines del siglo XIII y mediados del $\mathrm{XV}^{55}$. La propia villa terminaría por ser entregada, como pronto veremos, al marqués de Villena, ese nuevo poder emergente que había surgido en el reino de Castilla tras la batalla de Olmedo. El proceso de absorción de Alarcón por parte del privado del príncipe tuvo dos fases. En una primera fase, hacia 1444, Pacheco había conseguido por parte de Juan II que, a cambio de su renuncia a la villa soriana de Agreda, se le darían 1.000 vasallos en las villas de Villena, Sax y Yecla, y sí estas tres no alcanzaban juntas esa suma, los restantes vasallos se completarían concediéndole varias aldeas de Alarcón ${ }^{56}$. Justamente era esto lo que quería Juan Pacheco, quedarse con las tres villas citadas y apoderarse si era preciso de algunas aldeas de Alarcón para que ésta cayese después en su poder como fruta madura. Se averiguó, más tarde, que Villena, Sax y Yecla contaban en total 420 vasallos. En consecuencia, el resto hasta cumplir los 1.000 que se le habían prometido se fijaron en varias aldeas de Alarcón, en concreto en Hontanaya, Tres Juncos, Montalbarejo, Robledillo, Las Pedroñeras y Las Mesas que de inmediato fueron eximidas de la jurisdicción de la villa y agregadas a Belmonte. Fácil es de suponer que tras éste despojo Alarcón terminaría siendo absorbida por Pacheco. La segunda fase de cerco a la villa se completó en 1446. En efecto, pocos días después del acuerdo de Astudillo, y como resultado directo del mismo, una cédula de Juan II, fechada el 23 de mayo de 1446, ponía en manos de Juan Pacheco la codiciada presa ${ }^{57}$. El monarca le concedía Alarcón por su decidida participación junto al bando real en la batalla de Olmedo. Pero en realidad, como sabemos, Pacheco había sido ya ampliamente recompensado por su contribución a ese combate. La justificación de esa donación carecía, pues, de sentido, pues Alarcón se le daba en realidad por la reconciliación de Astudillo, y obedecía como tantas otras a una nueva petición personal del príncipe a su padre, y también, y muy principalmente, al temor de don Álvaro a perder de nuevo un aliado poderoso que manejaba a su antojo la voluntad del heredero del trono y podría, por tanto, crearle problemas en el futuro. A fin de tenerle contento una vez más - no sería desde luego la última- le concedía lo que pedía. Años más tarde, el nuevo señor de Alarcón procedería a comprar algunas otras aldeas situadas en el término de esa villa, que no había podido incorporar tras la donación real porque pertenecían desde antiguo a otros señores. Con estas adquisiciones trataba de ampliar y consolidar su dominio en la tierra de Alarcón. Así, en

\footnotetext{
${ }^{55}$ Alfonso Franco Silva, En la Baja Edad Media, p. 429.

${ }^{56} \mathrm{ADF}$, Catálogo Antiguo, Leg. 3, n ${ }^{\text {o }} 8$. Este documento lo he publicado en mi libro Estu dios sobre Ordenanzas Municipales, pp. 62-64.

${ }^{57} \mathrm{ADF}$, Catálogo Antiguo, Leg. 4, números 8 y 9 y Leg. 46, $\mathrm{n}^{\circ}$ 15. He publicado el documento en el que el príncipe de Asturias confirma la donación real de Alarcón a Pacheco, En la Baja Edad Media, pp. 436-441.
} 
1458 compraba a Lope de Alarcón, antiguo alcaide de la villa, por 111.880 mrs. unas casas en Alarcón y las extensas dehesas de Gascas, Villalba y Vado el Parral ${ }^{58}$. Poco después, y en ese año, adquiría a ese mismo personaje el lugar de Zafra - convertido poco después en villa - con sus dos alquerías, por $700.000 \mathrm{mrs}$. y un juro anual de $22.000 \mathrm{mrs}$. situado en las alcabalas de Alarcón ${ }^{59}$. En consecuencia, Pacheco lograba con estas compras un dominio completo sobre la tierra de Alarcón.

Se equivocaba de nuevo don Álvaro si pensaba haber contenido a Pacheco en sus desmedidas ambiciones. El condestable, una vez más, creía que el privado del príncipe podía sentirse definitivamente satisfecho en sus pretensiones. Se le había concedido el marquesado de Villena, una dignidad de primer rango en Castilla; a su hermano se le había también premiado nada menos que con una potencia económica y militar de tanta importancia como el maestrazgo de la orden de Calatrava; se les había dado, en fin, a ambos hermanos toda una amplia serie de señoríos sobre ricas y bien pobladas villas, además de oficios cortesanos y rentas de gran valor. En definitiva, se les había hecho grandes señores en el reino. Habían salido, por así decirlo, de la nada y se les había elevado a la más alta nobleza de Castilla ¡Qué más podían aún pedir! Craso error el del condestable, pues ambos hermanos - "maestres tan prosperados como reyes" en palabras del poeta Jorge Manrique- eran insaciables en sus ambiciones y no se detendrían nunca en su codicia con objeto de conseguir, más prebendas, más dignidades, más señoríos a costa de una corona a la que procuraban debilitar cada vez más. La difícil coyuntura política del reino - a río revuelto ganancia de pescadores- y el control casi total que ejercían sobre el heredero del trono - arrímate a buen árbol que buena sombra te dará- les permitiría alcanzar una buena parte de sus objetivos. Por de pronto tratarían por todos los medios a su alcance de debilitar la posición de don Álvaro para medrar a su costa.

La concordia de Astudillo no podía ser duradera, pues, como bien ha sugerido Suárez Fernández, encomendar el gobierno del reino a don Álvaro y a Pacheco no podía dar buenos resultados, tratándose de dos personalidades tan opuestas entre sí y con objetivos políticos tan dispares. Muy pronto surgieron las desavenencias entre el rey y el príncipe. El halconero de Juan II culpa de ello como siempre a Pacheco ${ }^{60}$ :

"La fama era que el Príncipe lo fazía (trataba de levantar caballeros contra el rey y el condestable) por ynducimiento de don Jhoan Pacheco, marqués de Villena, su criado, al qual se presume que lo fazia a fin de sacar del Rey algunos yntereses, según que lo avía acostunbrado, e asimismo por desviar al dicho condestable e maestre de Santiago de la corte; por que él así desviado, podiese con el fabor del Príncipe mandar en el rreyno más que otro alguno".

\footnotetext{
${ }^{58} \mathrm{ADF}$, Caja $100, \mathrm{n}^{0} 7$.

${ }^{59} \mathrm{ADF}$, Caja $100, \mathrm{n}^{\mathrm{o}} 5$.

${ }^{60}$ Crónica del Halconero de Juan II, cap. CCCL, p. 478 y ss.
} 
El cronista de Juan II es también de la misma opinión ${ }^{61}$ :

"Lo qual hazia por inducimiento de D. Juan Pacheco, Marqués de Villena, porque con aquellas rescibiese mercedes é acrecentase su estado".

A la altura de 1447 el príncipe y Pacheco trataban de agrupar en una liga a todos los nobles descontentos con la política de don Alvaro. El fin último era, como afirma Suárez, "socavar las bases del poder de D. Alvaro" para procurarse recursos económicos cada vez mayores ${ }^{62}$. Una política semejante sólo podía perjudicar "el prestigio y la autoridad del rey" 63 . Don Enrique se presentaba así ante el reino como una persona "más pendiente de los apetitos de sus consejeros que del bien de este último". El condestable se veía así obligado a negociar con Pacheco y Girón para ganarse al heredero. Por su parte, a la nobleza sólo le preocupaban sus intereses como grupo, y para ello trataban de fortalecer el partido del príncipe porque eso les beneficiaba en su objetivo de conseguir un régimen político en el que el poder se ejerciese de forma compartida entre el rey y ellos ${ }^{64}$.

El condestable trató entonces de solventar esas diferencias que separaban al príncipe de su padre por el camino de la división entre los propios personajes que apoyaban al heredero del trono. Así, intentó atraer a su bando en primer lugar al noble más díscolo, el almirante, a quien ofreció como señuelo la villa de Tarifa y un juro de $100.000 \mathrm{mrs}^{65}{ }^{6}$. Después hizo lo propio con su pariente, el conde de Benavente. La desafección del almirante y de Benavente hizo que el príncipe quedase reducido a sus consejeros más íntimos, Pacheco y Girón, y al conde de Castro ${ }^{66}$. La respuesta del heredero y de sus fieles fue el recurso a las armas. Al final, como siempre, se produjo la concordia, porque éste era precisamente el modelo de actuación que Pacheco había inculcado en el príncipe: "la alternancia de rebelión y pacto, para aumentar lentamente los dominios privados de don Enrique y al mismo tiempo los suyos propios" ${ }^{67}$. De nuevo los dos privados acordaron un pacto. En realidad el nuevo acuerdo no era más que una tregua porque se limitaba a reproducir los acuerdos de Astudillo ${ }^{68}$. La situación al día siguiente de esta concordia seguía siendo la misma, porque don Álvaro, tratando de aferrarse a un poder que veía por momentos escapársele de las manos, no contemplaba ya otro método que el recurso a la fuerza ${ }^{69}$. Esta es la explicación que hay que darle a la reconciliación entre padre e hijo por don Âlvaro en la aldea de

\footnotetext{
${ }^{61}$ Crónica de Juan II, 1446, cap. IX, p. 652.

${ }^{62}$ Luis SUÁREZ FERNÁNDEZ, Enrique IV, p. 72.

${ }^{63}$ Ibídem.

${ }^{64}$ Ibídem, p. 73

${ }^{65}$ Luis SUÁREZ FERnÁNDEZ, Los Trastámaras, p. 194 y Crónica del Halconero, 1447, cap. CCCL, pp. 478 y ss.

${ }^{66}$ Ibídem.

${ }^{67}$ Ibídem.

${ }^{68}$ Crónica del Halconero, cap. CCCLV, p. 488-489.

${ }^{69}$ La situación política la describe muy bien, como siempre, Luis SUÁREZ FERNÁNDEZ Los $T$ rastámaras, pp. 194 y ss.
} 
Záfraga, en las afueras de Medina del Campo, el 11 de mayo de $1448^{70}$. Záfraga, en opinión del profesor Suárez Fernández, fue el más grave error que pudo cometer el condestable Luna, pues pensaba que con las recompensas que ofrecería a Pacheco - el príncipe por su parte obtenía Logroño- le comprometía personalmente en su cada vez más arriesgada política ${ }^{71}$. De hecho Záfraga supuso para Girón la incorporación de una villa de tanta importancia estratégica como Peñafiel. Esta villa había pertenecido a los dominios de Juan de Navarra para pasar después, tras el acuerdo de Astudillo a manos del príncipe Enrique, que muy gustoso la concede a Girón en 1448. De esta manera, el hermano del marqués de Villena lograba crear un extenso señorío, a costa de los infantes de Aragón, formado por las villas de Urueña, Tiedra, Peñafiel y, más tarde, aunque por poco tiempo, San Felices de los Gallegos, además de la renta de los cambios de Medina del Campo ${ }^{72}$. Pacheco, por su parte, consigue de don Álvaro de Luna una participación importante en el gobierno del reino ${ }^{73}$. Y, por supuesto, la donación de nuevas villas que este personaje siempre exigía tras cualquier acuerdo u oportunidad que se le presentase. Un año antes de Záfraga había logrado incorporar a su patrimonio nuevas villas del antiguo marquesado de Villena. En efecto, el 16 de marzo de 1447 utilizó la villa de Medellín para cambiarla con el príncipe, éste se quedaba con esta última y Pacheco recibía a cambio Chinchilla y el Castillo de Garci-Muñoz, dos importantes pueblos del marquesado que ahora pasaban a su poder ${ }^{74}$.

Chinchilla y el Castillo de Garci-Muñoz pertenecían al príncipe por la donación que su padre le había hecho de todo el marquesado de Villena con la expresa condición, que desde luego no se cumpliría, de que todas sus villas estuvieses "vinculadas e condiçionadas perpetuamente a la mi corona real sin se apartar nin poder della ser apartadas". Don Enrique, con tal de satisfacer a su privado, hizo caso omiso del mandato paterno. La justificación para llevar a cabo el trueque es la misma que en casi todos los casos de esta índole: "E otrosí avida consideraçión e acatamiento a los grandes peligros a que se ha puesto por mi serviçio e vuestro, lo qual todo es a mi conosçido e notorio e

${ }^{70}$ Ibídem, pp. 196 y ss. Sobre Záfraga las noticias que recoge el Halconero, cap. CCCLXIV, pp. 499 y ss.

${ }^{71}$ Luis SuÁREZ FERNÁNDEZ, Nobleza y Monarquía, Valladolid, 1959, p. 125. Sobre el descontento de la nobleza ante el giro que tomaban los acontecimientos políticos desencadenados por don Alvaro de Luna basten estas palabras del cronista: "é por esto así los grandes como los medianos, e aún los menores caballeros destos Reynos estaban muy sentidos y escandalizados y descontentos creyendo que este daño se podía extender a todos; é creían que esto se hacía porque al Maestre Don Alvaro de Luna no quedase embargo alguno para en todo hacer su libre voluntad", Crónica de Juan II, 1448, cap. IV, p. 658 .

${ }^{72}$ Luis SUÁREZ FERNÁNDEZ, Los Trastámaras, p. 188.

73" "Don Alonso de Fonseca, Obispo de Ávila que después fue Arzobispo de Sevilla y de Santiago, trató con el Maestre don Alvaro de Luna, Condestable de Castilla, y con el Marqués de Villena Juan Pacheco secreta confederación e amistad, mostrándoles como seyendo ellos juntos el uno con el Rey, y el otro con el Príncipe, los governarían en su querer"; Crónica de Jüan II, 1448 , cap. II, p. 656. Sobre el obispo Fonseca y su intervención en esta coyuntura política mi trabajo El Arzobispo de Sevilla Alonso de Fonseca el Viejo. Notas sobre su vida, "Boletín de la Real Academia de la Historia", CXCVI/I (1999), pp. 43-44.

${ }^{74} \mathrm{ADF}$, Caja 105, no 3. 
lo hé e aproeuo e declaro por tal". El trueque era muy favorable para Pacheco porque, aunque las rentas de Medellín eran mayores que las de Chinchilla y el Castillo de Garci-Muñoz, el príncipe le cedía también esa demasía a su favorito. Pronto, Pacheco, terminaría por hacerse con todas las villas que habían formado parte de esa antigua demarcación territorial. Pero fue al año siguiente cuando su ya de por sí sólido patrimonio se incrementa de manera muy notable, aprovechando a su favor la coyuntura que se había creado tras el golpe de Záfraga. Algo que ya formaba parte de sus métodos de actuación. El príncipe, además, le confirma en los oficios que ejercía en la ciudad de Segovia y en la tenencia de la villa de Molina ${ }^{75}$. El 16 de enero de 1448 su protector le hace una nueva merced: la tercera parte de todo el dinero que debían entregar en ese año al príncipe sus mayordomos y recaudadores, asî como $100.000 \mathrm{mrs}$. que se le debían de acostamiento del año anterior ${ }^{76}$. Meses más tarde, en agosto de ese año, don Enrique, tras conseguir de su padre la donación de Logroño, le entrega a Villena de por vida la tenencia de los alcázares y fortalezas de esa ciudad, y ordena a su chanciller, Diego Almires, que le dé posesión de esos oficios ${ }^{77}$. Finalmente, en los últimos meses de 1448, Pacheco recibirá dos nuevas e importantes villas. En septiembre será la villa de Moya la que caiga en su poder, y en octubre el Barco de Ávila ${ }^{78}$. La primera estaba próxima a sus dominios manchegos y, aunque la perdería más tarde, interesaba al marqués para redondear y dar homogeneidad a su patrimonio. La segunda exige, por nuestra parte, una correcta explicación.

Tras el golpe dado en Záfraga por el condestable, con el visto bueno del príncipe y de Pacheco, fueron reducidos a prisión los condes de Alba y de Benavente, don Enrique Enríquez y Pedro y Suero de Quiñones, todos ellos enemigos declarados de don Alvaro, como también lo eran el almirante y el conde de Castro que, sin embargo, habían logrado darse a la fuga ${ }^{79}$. La acción de Záfraga era verdaderamente descabellada porque, como opina, Suárez Fernández, el condestable, "al declarar la guerra a la nobleza de forma tan radical, se cerró el camino de cualquier posible reconciliación futura" ${ }^{80}$. Fue, continúa diciendo el profesor Suárez, un golpe "inútil”, porque, aparte de que el acuerdo con el príncipe "fue tan breve" como los anteriores, "no pudo crear una situación política nueva, a pesar de las confiscaciones que siguieron, y en adelante su figura quedaría aislada, como símbolo de la arbitrariedad"81. Acabamos de ver las recompensas que tanto el príncipe como Pacheco recibieron como consecuencia de dar su consentimiento al golpe de don

\footnotetext{
${ }^{75}$ ADF, Catálogo Antiguo, Leg. 6, no 1 y Catálogo Antiguo, Leg. 4, no 11.

${ }^{76} \mathrm{ADF}$, Catálogo Antiguo, Leg. 4, números 12, 13 y 14.

${ }^{77} \mathrm{ADF}$, Catálogo antiguo, leg. 4, números 15 y 21.

${ }^{78}$ La donación de Moya en ADF, Catálogo Antiguo, Leg. 4, números 16 y 19. Transcribo este documento al final de este trabajo. La donación đel Barco de Avila en ADF, Caja 2, n⿳0 24.

${ }^{79}$ Crónica de Juan II, 1448, cap. X, p. 657; Crónica del Halconero de Juan II, cap. CCCLXIV, p. 499 y 500 y Luis SUÁREZ FERNÁNDEZ, Los Trastámaras, p. 196.

${ }^{80}$ Luis SuÁREZ FERNÁNDEZ, Los Trastámaras, p. 196.

${ }^{81}$ Ibídem.
} 
Álvaro. Sin embargo, como sucedía siempre, la colaboración entre el partido del príncipe y el que representaba don Álvaro duró bien poco. Se rompería cuando don Enrique, asesorado por Pacheco, exigió entre las prebendas a recibir, además de Logroño que la obtuvo como hemos visto, el mando sobre toda la frontera de Granada, con poderes excepcionales ${ }^{82}$. Pacheco esperaba, que esta última merced se le negaría a su protector, como así, en efecto, sucedería, pues para el marqués de Villena el mando sobre esa frontera no era más que un pretexto para distanciarse de nuevo de don Álvaro, y a continuación volver a pactar con él y arrancarle nuevas concesiones. Al condestable no le quedaría más remedio que intentar de nuevo una concordia. Esta se llevaría a cabo en Tordesillas. Como siempre el precio impuesto por Pacheco fue muy alto. Exigió Moya, el Barco de Avila y las villas principales que se le habían confiscado al conde de Castro. Moya, como hemos visto, se le concedió rápidamente, en el mismo mes de septiembre en que habían tenido lugar las vistas de Tordesillas. El Barco de Ávila caería en su poder el 20 de octubre $^{83}$. Esta última villa formaba parte de la jurisdicción del conde de Alba, uno de los represaliados por el golpe de Záfraga. Juan II así lo manifiesta expresamente en el privilegio de donación: "con acuerdo del príncipe don Enrique... por los muchos y graves y enormes casos, crímenes, delictos e cosas cometidos así contra mi persona e contra la corona real commo contra el bien e pro común de mis regnos, que son públicas, notorias e conosçidas, mandé prender a los condes de Benavente e de Alba, y a don Enrique, hermano del almirante don Fadrique, a Pedro de Quiñones y Suero de Quiñones, su hermano, y me apoderé de todas sus villas, y así mismo embargué las villas del almirante don Fadrique y las de don Diego Gómes de Sandoval, conde de Castro, las de Juan de Tovar, mi guarda mayor, las de Fernando de Rojas, adelantado mayor de Castilla y las de don Diego, su hermano, hijos del conde de Castro, y todos pedieron sus villas y se les confiscaron para la cámara e fisco, y quiero y mando que de aquí adelante non sean avidos por sennores de cosa alguna dello".

Si el conde de Alba perdía una de sus villas más significativas, el conde de Castro perdía a su vez Cea y Castrojeriz, la villa que le daba título ${ }^{84}$. Tanto el Barco de Ávila, como las villas del conde de Castro, serían recuperadas años más tarde, como casi siempre solía suceder, por sus titulares cuando la coyuntura política así lo exigía, pero mientras tanto Pacheco podía disfrutar de sus rentas y utilizarlas en su momento oportuno para, por el procedimiento de la devolución o del trueque, hacerse con otras de más entidad o de mayor interés para sus fines.

\footnotetext{
${ }^{82}$ Ibídem.

${ }^{83}$ Véase nota $\mathrm{n}^{\mathrm{o}} 78$.

${ }^{84}$ Alfonso FrANCO SILVA, Señores y Señorios, p. 101. La villa de Cea sería recuperada años más tarde, en 1456, tras la reconciliación entre Enrique IV y Juan de Navarra, por el hijo del conde don Fernando Gómez de Sandoval. Castrojeriz, en cambio, como veremos, sería intercambiada por Iniesta.
} 


\section{De ZÁfraga AL FINAL DEL REINAdo DE JUAN II}

La reconciliación de Tordesillas, en la que el condestable y Pacheco acordaron repartirse la gobernación del reino, duró muy poco.. Los nobles represaliados en Záfraga y Tordesillas, a los que se unieron pronto otros "grandes" descontentos con la política que estaba llevando a cabo don Álvaro desde el golpe, proclamaron la necesidad de acabar con el condestable, reconstruir la liga nobiliaria, pedir ayuda al rey de Navarra e intentar atraer a su bando al príncipe heredero ${ }^{85}$. A partir de entonces se inicia una compleja serie de acontecimientos, que han sido analizados por Suárez Fernández, que desembocarán en las vistas de Coruña del Conde, en julio de 1449, en las que se constituyó secretamente la gran Liga nobiliaria en la que entraron a formar parte el príncipe, los partidarios del rey de Navarra, los condes de Haro, Plasencia y Benavente, el marqués de Santillana y otros ${ }^{86}$. Parecía inminente un enfrentamiento armado de estos nobles contra las tropas del rey y del condestable. Pero de nuevo se impuso la reconciliación entre padre e hijo. Villena fue, como siempre, el factotum de tal acuerdo, que en la práctica significaba una traición a la palabra dada a los integrantes de la Liga que se habían conjurado en Coruña del Conde ${ }^{87}$. La nueva concordia tuvo lugar en el lugar de Palomares, cerca de Huete, en el que se entrevistaron don Alvaro y Pacheco ${ }^{88}$. Acordaron entonces la entrega al príncipe de la ciudad de Burgos y, a cambio, éste se comprometía a no intervenir en los problemas que estaba planteando la ciudad de Toledo, rebelada contra don Álvaro ${ }^{89}$. Don Enrique, como siempre, no cumpliría ese acuerdo y, poco después, en noviembre de 1449, hizo de nuevo su entrada en Toledo, ciudad ésta que pasaba a partir de ahora a los ya extensos dominios del heredero del trono ${ }^{90}$. El príncipe regresó después a Segovia dejando la alcaidía del alcázar de la ciudad del Tajo a su fiel Girón. Desde entonces, como afirma el profesor Suárez, el heredero del trono se convirtió "en el más fuerte poder de Castilla" movimientos Pacheco supo sacar partido. Se le confirmó en la posesión de Almansa, Chinchilla, Alarcón, Castillo de Garci-Muñoz, Yecla y Sax, y obtuvo además de Alfonso $\mathrm{V}$ la orden de la insignia de la Jarra ${ }^{92}$. Logró obtener también seguro y promesa real, con juramento y pleito-homenaje por parte del monarca, de que no toleraría jamás que el rey de Navarra le arrebatase la villa de Chinchilla, ni tampoco las demás que le habían sido

\footnotetext{
${ }^{85}$ Luis SUÁREZ FERNÁNDEZ, Los Trastámaras, pp. 197-198.

${ }^{86}$ Ibídem, p. 201. Crónica de Juan II, cap. XI, p. 669.

${ }^{87}$ Ibídem.

${ }^{88}$ Ibídem.

${ }^{89}$ Ibídem.

${ }^{90}$ Ibídem.

${ }^{91}$ Ibídem, p. 202.

${ }^{92}$ La confirmación de Almansa en ADF, Catálogo Antiguo, Leg. 46, números 16, 17 y 19 y Catálogo Antiguo, Leg. $4, n^{\circ} 17$ y la concesión de Âlfonso V en Cátálogo Antiguo, Leg. 56, sin numerar.
} 
concedidas del marquesado de Villena ${ }^{93}$. En caso contrario, se le daría una adecuada recompensa por esa pérdida. Para dar mayor solemnidad al seguro, ya que Pacheco temía, no sin fundamento, el regreso del rey de Navarra a Castilla, Juan II se vio obligado a prestar el juramento en manos de don Álvaro de Luna.

A la altura del año 1450 todo parecía irle bien a don Juan Pacheco. El dominio que ejercía sobre la voluntad del príncipe, y la necesidad que don Álvaro tenía del concurso y apoyo del heredero del trono para contener a sus muy numerosos enemigos, sólo le habían reportado ganancias y ningún contratiempo. Sin embargo, esta entente cordial entre protector y protegido dio por primera vez señales de desacuerdo en ese año. Fue el episodio de Rodrigo Portocarrero, un joven que había sido introducido por el propio Pacheco en la Casa del príncipe, al ser hermano bastardo de su mujer. La desavenencia entre don Enrique y la persona que hasta ese momento había gozado de toda su confianza, aunque fue breve, parece debida a una cierta percepción por parte del primero de que estaba siendo manejado por completo por ambos hermanos. Esta es la opinión de Luís Suárez, pero en realidad las causas y circunstancias que provocaron ese desencuentro siguen siendo muy oscuras. Y desde luego el asunto tuvo una gran trascendencia para sus propios contemporáneos, pues lo mencionan de forma somera el autor de la Crónica de Juan II y con cierto detalle descriptivo el Halconero Carrillo de Huete, ambos siempre bien informados. Son los únicos testimonios que han llegado hasta nosotros sobre episodio tan particular, pero al mismo tiempo tan revelador de que don Enrique parecía pretender deshacerse de la abrumadora influencia que hasta entonces había ejercido sobre su persona el marqués de Villena. El Halconero de Juan II describe así los hechos que condujeron a la ruptura $^{94}$ :

Rodrigo Portocarrero era mancebo de fasta 22 años, fijo borde de Pedro Portocarrero, el qual dicho marqués [Villena] avía traydo a la casa del Príncipe, por ser hermano de su muger.... E por quanto el señor Prínçipe se pagava mucho de los ginetes, más que de los omes de armas, e aqueste Rodrigo era manceuo de buen cuerpo, e cavalgava bien a la gineta, e lançaua vien lança a cavallo, por lo qual el señor Principe tomó con él tanto amor, que los dichos maestre e marqués, con los celos que dello ovieron, touieron manera de lo apartar del señor Prínçipe. El Prínçipe tuvo mucho enojo dello [y decidió enviar a Rodrigo a su villa de Medellín]... E en este comedio creçió el amor en el Príncipe con el dicho Rodrigo Portocarrero mucho más en ausencia que no en presençia, tanto que le fizo merced de la villa de Medellín e su tierra".

El cronista de Juan II, aunque menos descriptivo, ofrece datos de mayor importancia ${ }^{95}$. En efecto, y según este autor, el príncipe, de acuerdo con el obispo Lope Barrientos, el mariscal Payo de Ribera, el alférez Juan de

\footnotetext{
${ }^{93} \mathrm{ADF}$, Catálogo Antiguo, Leg. 49, n ${ }^{\circ} 5$.

${ }^{94}$ Crónica del Halconero de Juan II, cap. CCCXXXVII, p. 543.

${ }^{95}$ Crónica de Juan II, cap. I, p. 672. Información muy semejante en Gonzalo CHACón, Crónica de D. Alvaro de Luna, Edición de Juan de Mata CARRIAZO, p. 250.
} 
Silva y el propio Rodrigo Portocarrero, trató de desembarazarse de su privado y llegó a pensar en ponerle en prisión. Pacheco fue advertido de la maniobra que se había urdido contra su persona, y puso de inmediato pies en polvorosa. Se refugió, entonces, en una calle de Segovia llamada la Calongia y de allí ciertos cómplices le ayudaron a escapar a la villa de Turégano. Hasta aquí las noticias que sobre este episodio nos proporciona el cronista de Juan II. Carrillo de Huete, por su parte, nos ofrece más detalles de lo que sucedió tras la fuga de Pacheco ${ }^{96}$. El príncipe, tras conocer la huída de su privado, se enojó de forma considerable porque "non podía vien asentar su voluntad, según solía, con Pacheco y Girón", entre otras razones "porque no se hallava tan libre e tan exçento para allegar a sy al dicho Portocarrero", y porque, además, ambos hermanos "tenían todas las fortalezas del Prínçipe, e con rreçelo que no se le alçasen con ellas non osava seguir algunas causas que le cumplian, antes azía otras muchas cosas contra su voluntad, por este rreçelo... el Príncipe andava... pensando cómo ge las quitaria".

El hecho cierto es que el plan por parte del heredero de intentar prescindir de los servicios que hasta entonces le habían hecho Pacheco y Girón, si es que realmente existió una verdadera voluntad de desembarazarse de ellos, no dio resultado alguno, lo que demuestra bien a las claras de que don Enrique, a la altura de 1450, no era ya capaz de quitarse de en medio a esos dos servidores que desde niño le venían dictando las decisiones que debía tomar ante cualquier problema que se le presentase. Le faltaba fuerza de voluntad para adoptar una medida que podría haber sido tan trascendente para él y para el futuro del reino, lo que prueba, una vez más, que la araña tejida por Pacheco alrededor de su persona y de sus intereses, a lo largo de tantos años, era tan tupida y densa que no era capaz de desenredarla. En eso había consistido la gran jugada del marqués de Villena, se había hecho tan imprescindible y tan necesario que don Enrique, aún deseándolo, no podía ya prescindir de él. Carrillo de Huete lo da a entender de forma bien clara cuando dice que el príncipe no era del todo libre para desembarazarse de Pacheco y Girón porque desde hacía años les había entregado las tenencias de las fortalezas que poseía, y desde ellas podían muy fácilmente hacerse fuerte y declararse en rebeldía. No tenía, por tanto, libertad plena para poder tomar una decisión semejante. Así pues, no podía extrañar a nadie, dadas esas circunstancias, que Pacheco y Girón regresasen bien pronto al redil, o dicho de otra manera volviesen a hacerse cargo de los negocios de don Enrique como privados favoritos, lo que habían sido hasta entonces y continuarían siéndolo, con algunos altibajos, hasta el final de sus vidas.

Al cabo de veinte días el marqués de Villena regresó a Segovia y se reconcilió con su protector. Pero para recuperar la plena confianza de don Enrique necesitaba a toda costa alejar a Portocarrero de la corte principesca, porque había comprobado que podía convertirse en un rival poderoso que podía apartarle de la privanza. Temiendo perder la posición que había

${ }^{96}$ Crónica del Halconero de Juan II, cap. CCCLXXXV, p. 540. 
alcanzado, a base de intrigas, a lo largo de muchos años, y tras ella también su patrimonio, concibió entonces una jugada magistral: casarlo con una hija bastarda suya y procurarle un señorío digno que le mantuviese permanentemente alejado de don Enrique. El matrimonio con doña María Pacheco "non plazia al dicho Puertocarrero, ni tampoco al Príncipe, pero por sacar el alcaçar de Segovia del dicho marqués", ambos aceptaron el hecho ${ }^{97}$. El príncipe concedió entonces a Rodrigo el señorío sobre la villa de Medellín. Pacheco había ganado la batalla, aunque esa maniobra tan astuta le obligase a renunciar a la tenencia del alcázar de Segovia, pero qué importaba ese precio si había salido vencedor y su rival, además de convertirse en su yerno, se veía obligado a abandonar la corte del príncipe de Asturias. Pero es que además la cesión del alcázar de Segovia no la había hecho gratuitamente. En cuanto pudo dominar de nuevo la voluntad de su señor procedió a solicitarle una compensación por esa renuncia. La recompensa, concedida por el príncipe el 20 de marzo de 1450, además de insólita por las circunstancias que habían incurrido en ella, fue extraordinariamente generosa, nada menos que la donación de Hellín, Albacete y Tábarra, con lo que se acercaba aún más a completar su dominio sobre el marquesado de Villena ${ }^{98}$. En realidad, más que perder por esa desavenencia tan breve, lo que había conseguido, tras el episodio de Rodrigo Portocarrero, fue ganar aún más. La jugada, por tanto, había sido maestra: Pacheco volvía a la privanza con el príncipe, incorporaba nuevos señoríos de gran valor y se disponía a seguir participando directamente, como lo había hecho hasta entonces, en los acontecimientos políticos del reino, pese a que, para Suárez Fernández "las relaciones entre ambos habían cambiado de forma definitiva, a partir de entonces el príncipe buscaría con más empeño nuevos hombres" 99 . Yo, en cambio, no suscribiría del todo esta opinión, porque si bien es verdad que el futuro monarca trataría de encontrar

\footnotetext{
${ }^{97}$ Ibídem.

${ }^{98} \mathrm{ADF}$, Catálogo Antiguo, Leg. 6, n ${ }^{\mathbf{0}}$ 30. La toma de posesión de Hellín en Caja 3 , n ${ }^{\circ} 1$. Fue el 22 de junio de 1450. Previamente a la toma de posesión, el concejo de Hellín exigió al bachiller Alfonso González de la Plazuela que, en nombre de su nuevo señor, jurase respetar las siguientes condiciones: a) guardaría todos sus privilegios y libertades, tal como lo habían hecho los señores que le habían precedido, y respetaría sus terminos; b) no podría vender, donar ni cambiar la villa con nadie; c) no podría imponer a la villa ni pedidos, ni monedas ni otro tributo alguno "porque así lo tienen de vso e costumbre y así lo habian respetado el rey y el prínçipe, su señor"; d) que guardase la exención del derecho de veintena que el príncipe había concedido a los “barraunos" - personas de fuera de la villa- que viniesen a vender o a comprar mercancías en ella; e) que la vịla no daría huéspedes porque no consentiría que "ningún sennor pueda aposentarse dentro del cinto de la puerta ferrada adentro porque nuncá han tenido esa obligación "; y e) el marqués de Villena perdonaría todos los delitos que cualquier vecino o morador de la villa hubiese cometido hasta el día de la toma de posesión. Sólo se le dio posesión de la villa cuando el bachiller, en nombre de su señor, juró que respetaría todas esas condiciones.

${ }^{99}$ Luis SuÁREZ FERNÁNDEZ, Enrique IV, p. 105. Emilio Cabrera, por su parte, sospecha que tras el episodio de Rodrigo Portocarrero, se encontraba el propio Alvaro de Luna y su aliado el maestre de Alcántara, don Gutierre de Sotomayor, que trataban de crear, disensiones entre los componentes de la camarilla del príncipe a fin de neutralizar las actividades de éste último (Emilio CABRERA, Beatriz Pacheco y los origenes del condado de Medellín, "Anuario de Estudios Medievales", 15 (1985), p. 520. En cualquier caso el príncipe Enrique no olvidaría a Rodrigo Portocarrero, y seguiría concediéndole mercedes. Así, en 1451, cuando ejercía el oficio de repostero mayor del príncipe, Rodrigo recibiría de éste la tenencia de la alcaldía de los alcázares de Ecija, según la habían ejercido hasta entonces Tello González de Aguilar y su hijo Tello de Aguilar; ADF, Caja 1, no 15.
} 
más tarde nuevos colaboradores, nunca se libaría por completo del marqués de Villena, muy probablemente porque o no pudo, o no tuvo verdadero interés por zafarse de su tutela. De hecho, Pacheco permanecería al lado de don Enrique hasta el final de su vida, sí exceptuamos, claro está, la etapa en que se separó de su protector para apoyar a su hermano don Alfonso, período éste que no iría más allá de tres años, como en su momento veremos y tendremos ocasión de explicar.

Por otra parte, la situación en el reino de Castilla en estos años de 1450-51 estaba favoreciendo, a no dudarlo, a don Álvaro de Luna. En 1450 había estallado una guerra civil en Navarra, con lo que las posibilidades de invasión del reino por los aragoneses, se esfumaban al estar concentrado en esa contienda su tradicional enemigo, Juan de Navarra ${ }^{100}$. Casi al mismo tiempo se producía una división en el seno de la camarilla del príncipe heredero con la huída de Pacheco por el asunto de Rodrigo Portocarrero. Ambos hechos fueron aprovechados por el condestable para dar un vuelco a su apurada situación política. De esta manera durante año y medio consigue restablecer su poder de gobierno en Castilla ${ }^{101}$. Su objetivo primordial seguía siendo evitar las posibilidades de reconstrucción de la Liga nobiliaria, y para ello necesitaba tener de su lado al príncipe de Asturias y, al mismo tiempo, neutralizar a Juan de Navarra, que continuaba intrigando sin cesar para regresar a Castilla y recuperar sus dominios. Lo segundo no le fue difícil. La guerra civil en Navarra obligaría a don Juan, a comienzos de diciembre de 1450 , a solicitar la paz con Castilla ${ }^{102}$. El cese de hostilidades entre ambos reinos tendría, como era lógico, importantes consecuencias. En primer lugar el perdón concedido por el condestable a los desterrados -el almirante, su hermano Enrique, Juan de Tovar y el conde de Castro- significaba en la práctica la disolución de la Liga nobiliaria ${ }^{103}$. Sin embargo, la pretensión de Juan de Navarra de que le fuera devuelto el maestrazgo de Calatrava a su hijo bastardo, Alfonso de Aragón, suponía el enfrentamiento con el príncipe heredero ya que esa dignidad, como sabemos, la venía desempeñando Pedro Girón desde el año $1445^{104}$. Don Álvaro, decidido a todo con tal de conseguir su principal objetivo de disolver la Liga, no dudó en satisfacer los deseos del rey de Navarra, aunque fuese al precio de una nueva desavenencia con don Enrique y Pacheco. El condestable sabía que el príncipe, al quedarse sin aliados, no tendría más remedio que capitular y, mientras tanto, al firmar la paz con Juan de Navarra, había logrado desarticular el peligro que para él suponía la Liga nobiliaria.

De momento, el cese de las hostilidades con Aragón y la concesión del maestrazgo de Calatrava a don Alfonso de Aragón parecían debilitar el

\footnotetext{
${ }^{100}$ Luis SUÁREZ FERNÁNDEZ, Los Trastámaras, p. 202.

${ }^{101}$ Ibídem.

${ }^{102}$ Ibídem, p. 204. El texto del tratado de paz, que lleva fecha del 8 de septiembre de 1451, en ADF, Catálogo Antiguo, Leg. 2, $\mathrm{n}^{\mathrm{O}} 12$.

${ }^{103}$ Ibídem, p. 202.

${ }^{104}$ Ibídem, p. 204.
} 
partido del heredero del trono. Girón, indignado por la posible pérdida de la dignidad que ostentaba, armó una hueste en Almagro, mientras que su protector se reunía con su hermano en Toledo ${ }^{105}$. Pronto, sin embargo, vendría la reconciliación, favorecida, además, por el fracaso de don Alfonso en su intento por recuperar el maestrazgo, ya que los caballeros de Calatrava se negaron a reconocerlo y de forma casi unánime decidieron prestar su apoyo a Girón ${ }^{106}$. Este, por su parte, ya se había encargado de emprender una expedición de castigo contra aquellos lugares, en especial Torrijos, que se habían declarado por el aragonés ${ }^{107}$.

La nueva reconciliación entre padre e hijo, o mejor entre el condestable y Pacheco, tuvo lugar en Tordesillas, en febrero de $1451^{108}$. A cada nuevo acuerdo, más prebendas para Villena. Ahora recibía, además de la confirmación de las villas de Moya, Hellín, Albacete y Tobarra, la concesión del señorío sobre Las Peñas de San Pedro ${ }^{109}$. Esta última villa se la donó Juan II atendiendo a las súplicas que le había hecho su hijo en Tordesillas. Su hermano Girón, por su parte, conseguía también, además de la confirmación del maestrazgo de Calatrava, bienes en la Puebla de Grado, los portazgos de Úbeda, Jaén y su tierra y la villa de Santisteban del Puerto, de la que, sin embargo, no llegaría a tomar posesión ${ }^{110}$.

Es evidente que ambos hermanos habían aprendido muy bien la lección que habían recibido del intento frustrado de don Enrique por promocionar al joven Rodrigo Portocarrero, tratando de esta manera de liberarse de la influencia verdaderamente asfixiante de sus dos privados. Al desaparecer don Rodrigo del entorno personal del príncipe para disfrutar de su lejano feudo, tras verse obligado a aceptar el plan de Villena de casarse con su hija bastarda, un plan como todos los suyos inteligente y maquiavélico, el heredero del trono no tuvo más opción que volver al redil y ambos hermanos a la privanza. Desde entonces, y a fin de evitar cualquier otro sobresalto de esta índole, van a tratar de tener más sujeto a don Enrique, y a estar más atentos a impedir en la medida de lo posible la promoción de cualquier otro aspirante a ocupar el puesto que detentaban. La prueba más evidente de que

${ }^{105}$ Ibídem.

${ }^{106}$ Ibídem, p. 205.

${ }^{107}$ Ibídem. La narración del saqueo de Torrijos en Crónica de Juan II, año 1451, cap. III, p. 673. Ana VIÑA, por su parte, recoge el testimonio del propio testamento de Pedro Girón, Morón y Osuna, p. 21 .

${ }^{108}$ Ibídem, p. 205. Sobre el pacto de Tordesillas hay abundantes noticias en Crónica de Juan II, año 1451, cap. VII , p. 675 . La jornada de Tordesillas fue definida por el cronista ALONSO DE PÁLENCIA, Crónica de Enrique IV, Libro II, cap. II, p. 36, con estos términos: "concordia clandestina y pacto funesto" para el interés general. Véase también a este respecto las opiniones de Luis SUÂREZ FERNÁNDEZ, Nobleza y Monarquía, p. 128.

${ }^{109}$ Las confirmaciones de Moya, Hellín, Albacete y Tobarra se recogen en el libro, ya citado, Noticias de todos los lugares de que se componen los Estados de Villena, existente en el ADF. El documento original de confirmación de Moya se encuentra en el ADF, Catálogo Antiguo, Leg. 4 , sin número. La donación de las peñas de San Pedro en ADF, Caja 31, $\mathrm{n}^{\circ} \mathrm{7}$. La facultad de Juan II a su hijo para que le donase esa villa lleva fecha del 25 de marzo, pero el albalá por el cual el príncipe le hacía esa merced lleva la fecha y el lugar de expedición en blanco.

${ }^{110}$ Javier AGUADO y Remedios MoRÁn, Papel del marqués de Villena en la formación del señorío de Osuna, en "Congreso de Historia del Señorío de Villena", Albacete, 1987, p. 20. 
habían recuperado la plena confianza del heredero son esas donaciones que éste último había arrancado a su padre en Tordesillas para satisfacer las ansias desmedidas de ambos hermanos. Pacheco conseguía así una nueva villa, Las Peñas de San Pedro y, lo que para él tenía más importancia, tres nuevas villas más que habían formado parte del antiguo marquesado de Villena que tan tenazmente trataba de reconstruir en su propio beneficio. En efecto, unos meses después de la concordia de Tordesillas, el 10 de agosto de 1451, el marqués de Villena recibiría de su amado protector las villas de Jorquera, Alcalá del río Júcar y Ves ${ }^{111}$. Hasta ese año de 1451, las tres villas del río Júcar habían pertenecido a la jurisdicción del contador mayor, Alfonso Pérez de Vivero, por donación de Juan $\mathrm{II}^{112}$. En el momento en que el monarca donaba esas villas a Vivero entregaba también Villena al doctor Pero Yáñez $^{113}$. Ambas donaciones no eran caprichosas ni fruto, por tanto, de la casualidad o del arbitrio del rey, al contrario se insertaban en el marco de una época de tensiones y contiendas entre la Corona y, tras ella, su mentor el privado Álvaro de Luna y los infantes de Aragón, que intentaban conquistar el poder en el reino de Castilla, aventura ésta que, como sabemos, finalizaría en 1445 con la derrota de los infantes en la batalla de Olmedo. Pero antes de llegar a este desenlace, a comienzos del año 1440, las tierras del marquesado de Villena fueron el escenario principal en el que se iba a desarrollar una de las fases de esta cruenta batalla por el poder. Fue por esta razón, según el profesor Aurelio Pretel, por la que Juan II entregó Villena al doctor Yáñez, porque de esa manera pensaban interponer un enclave controlado por un hombre fiel a la Corona entre las fuerzas enemigas de Juan de Navarra, que ocupaban una parte de las tierras que habían formado parte del antiguo marquesado, y los auxilios que podía recibir éste último del reino de Valencia $^{114}$. La donación de Jorquera, Alcalá y Ves a Vivero respondía también a causas semejantes. Pretel sostiene que el contador mayor había conseguido la jurisdicción sobre esas villas durante la época de lucha contra los infantes de Aragón y piensa, además, que ya en 1442 habían caído en su $\operatorname{poder}^{115}$. Alonso Pérez de Vivero y el doctor Pero Yáñez formaban parte de una generación de funcionarios - no hay que olvidar, además, a Rivadeneira y a Fernán López de Saldaña- que jugaron un destacado papel político en la corte de Castilla durante el reinado de Juan II $^{116}$. Algunos habían sido colocados en la administración por Álvaro de Luna, "hombres oscuros" y personajes menudos que supieron aprovechar sus carreras y su constante presencia junto al monarca para acceder a la pequeña nobleza. Este era el caso

\footnotetext{
${ }^{111}$ Alfonso Franco Silva, En la Baja Edad Media, p. 111.

${ }^{112}$ Ibídem, p. 106.

${ }^{113}$ Ibídem, pp. 106-107.

${ }^{114}$ Aurelio PRETEL MARÍN, Algunas acciones militares de Albacete y su comarca en las luchas de los infantes de Aragón, "Âl-Basit. Revista de Estudios Albacetenses", VII/10 (abril, 1981), p. 33 .

${ }^{115}$ Ibídem, pp. 38 y 43.

${ }^{116}$ Luis SUÁREZ FERnÁNDEZ, Nobleza y Monarquía, pp. 109-111.
} 
de Alonso Pérez de Vivero y también del doctor Pero Yáñez, personajes que han merecido mi atención en tres trabajos publicados hace ya algunos años ${ }^{117}$.

Con toda seguridad, la donación de Villena y las de Alcalá y Jorquera a esos dos funcionarios debió de hacerse de forma provisional a la espera de acontecimientos que pusieran fin definitivamente a las pretensiones de los infantes. Se trataba de evitar que cayesen en poder del rey de Navarra. Fue, por tanto, una consecuencia más de una coyuntura ciertamente delicada, aunque también pudiese influir en el monarca y en don Álvaro el deseo de premiar la lealtad y colaboración de ambos servidores. La solución debía ser provisional porque, cuando cesasen esas dificultades, esas villas así donadas serían de nuevo reclamadas por su legítimo señor que, como sabemos, era el príncipe heredero, que había recibido como dote las villas del marquesado de Villena cuando contrajo matrimonio con Blanca de Navarra. Lo prueba el hecho de que tanto Pero Yáñez como Vivero encontrarían múltiples dificultades y una fuerte oposición a la hora de afianzarse en sus nuevas posesiones. Los partidarios que el rey de Navarra tenía en esas villas eran aún numerosos e importantes, y sólo esperaban la ocasión propicia para que retornasen de nuevo a su antiguo amo. El combate de Olmedo provocó, sin embargo, un cambio total de la situación. La primera que retornaría a poder del príncipe fue Villena, tras la desaparición del doctor Yáñez. Las villas del Júcar, sin embargo, continuarían algunos años más en poder del contador mayor.

Pérez de Vivero había conseguido convertirse en señor de Jorquera, Alcalá del Júcar y Ves aprovechando las dificultades de la monarquía en su lucha contra los infantes de Aragón. Desaparecido este peligro, tras el episodio de Olmedo, no había ya razón alguna para que el contador mayor siguiese reteniendo las tres villas del Júcar, a no ser por la fuerte protección que le dispensaba don Álvaro de Luna. Probablemente hubiese seguido siendo señor de esas tres villas si no se le hubiese interpuesto en el camino el privado del príncipe que, además de que estaba a punto de cerrar el largo proceso que le había llevado la incorporación de la totalidad de las villas del marquesado de Villena, contemplaba con cierta preocupación cómo las villas de Vivero dividían casi en dos las posesiones que había adquirido recientemente ${ }^{118}$. Así pues, para Pacheco constituía empresa de la máxima urgencia arrebatarle, por decirlo así, las mencionadas villas y reintegrarlas a la primitiva unidad del señorío de Villena por el procedimiento que fuese necesario. La ocasión se le presentó en 1451, pocos días después de la firma del acuerdo de Tordesillas y, de nuevo, presionó al príncipe, esta vez de manera aún más fuerte que las anteriores, para que se las concediera. Don Enrique, a su vez, presionó al

\footnotetext{
${ }^{117}$ Sobre Vivero he publicado dos trabajos, Alonso Pérez de Vivero, contador mayor de Juan II de Castilla. Un traidor y su fortuna, recogido en mi libro La Fortuna y el Poder, Publicaciones de la Universidad de Cádiz. 1996, pp. 401-431, y Fuensaldaña y los Vivero. Un conflicto antiseñorial, "Hispania", LIX/3-203 (1999), pp. 823-855. Y sobre el doctor Pero Yáñez, Las primeras ordenanzas municipales de Villena (1440-1445), recogido en mi libro ya citado Estudios sobre Ordenanzas Municipales, pp. 37-67, en el que se encuentra también abundante bibliografía sobre este personaje.

${ }^{118}$ Aurelio PRETEL MARÍN, Las tierras albacetenses en la política castellana de mediados del siglo XV (1448-1453), "Anales del Centro de la UNED de Albacete", 5 (1983), p. 351.
} 
condestable para que éste hiciese lo mismo con su protegido, Vivero, y se aviniese, al fin, a ceder sus posesiones situadas junto al río Júcar.

El procedimiento utilizado por Pacheco para hacerse con la jurisdicción de esas tres villas fue el trueque. Era uno de los capítulos que se habían pactado en Tordesillas para la reconciliación del príncipe con su padre y el condestable. Juan II lo manifiesta muy claramente en el texto de la licencia que concedió a su hijo, el 24 de marzo, para realizar el trueque: don Enrique y él mismo se habían reunido en la villa de Tordesillas en febrero de ese año, acompañados por don Álvaro de Luna, el arzobispo de Toledo, Alfonso Carrillo, Juan Pacheco y algunas otras personas más que formaban parte del Consejo Real "por paçificar y allanar mis regnos y porque çesasen las muchas guerras y prisiones que se haçian de cada día y se esperaban continuar"119. Entre los capítulos que se firmaron y aceptaron por ambas partes figuraba uno muy especial, impuesto por el marqués de Villena: el trueque de las villas de Alcalá, Jorquera, Ves y La Roda —que también pertenecía al contador mayor - por la villa de Vivero - hoy Viveiro-, en la que, por cierto había nacido el protegido de don Álvaro y de la que había tomado su apellido. Alonso Pérez se vio presionado por su protector para dar su visto bueno al trueque. Lo aceptó desde luego, más bien de mala gana, aunque la operación le permitía hacerse con su villa natal, que, por cierto, había tratado de incorporar desde hacía muchos años a sus ya ricas posesiones ${ }^{120}$. En virtud de ese trueque, el príncipe se hacía con esas cuatro villas y, a cambio, entregaba al contador mayor la villa de Vivero, en tierras de Lugo, en el reino de Galicia, con el alfolí de la sal y el diezmo de la mar ${ }^{121}$. El segundo capítulo pactado en Tordesillas referente a este trueque constituía el verdadero detonante de la operación, la razón de ser de la misma: el rey quedaría obligado a dar licencia al príncipe de Asturias para que en ella hiciese merced de esas cuatro villas a don Juan Pacheco. Este último, en un plazo no superior a los cincuenta y cuatro días, debería entregar esas cuatro villas al arzobispo de Toledo, con todos los pertrechos militares y otros bienes que el contador mayor poseía en esas fortalezas, y además los bienes que guerreros a sueldo del propio Pacheco habían tomado y robado en ellas cuando fueron ocupadas por orden del príncipe ${ }^{122}$. Así mismo, Pacheco quedaba obligado a indemnizar a Vivero con la cantidad en que se estimase todo aquello que esa hueste hubiese gastado en utensilios, armas y enseres de esas fortalezas mientras las había tenido ocupadas. El marqués, como siempre, se comprometía bajo juramento a satisfacer esa deuda, pero en la realidad nunca lo haría. Vivero, por su parte, dentro del plazo ya mencionado, entregaría al arzobispo la villa

\footnotetext{
${ }^{119}$ ADF, Catálogo Antiguo, Leg. 5.

${ }^{120}$ Sobre las posesiones que logró acumular el contador mayor, mi libro La Fortuna y el Poder, pp. 414 y ss. y el artículo Fuensaldaña y los Vivero, publicado en la revista "Hispania", citado en nota 117, pp. 828-829.

${ }^{121}$ ADF, Catálogo Antiguo, Leg. 5.

${ }^{122}$ Según se expresa en un documento conservado en el Leg. 5 del ADF, Vivero también había ocupado la villa de Urueña que se hallaba bajo la jurisdicción de Pedro Girón. En virtud de estos acuerdos el contador tuvo que devolver esa última villa a su antiguo señor.
} 
de Urueña con su fortaleza y con todos los bienes muebles y pertrechos que en ellas había al tiempo que fue ocupada por su hueste. Una vez satisfechas y cumplidas esas exigencias se procedería entonces a realizar el trueque propiamente dicho. A este respecto, el príncipe y Pacheco se comprometían, bajo juramento y promesa, a no perturbar ni inquietar al contador mayor en el señorío y posesión de la villa de Vivero, y le ayudarían a que dentro del plazo previsto se otorgasen todas las facultades y escrituras que concerniesen a la operación de trueque. El príncipe cumplió lo prometido, y así el 3 de abril de 1451 entregó en Olias (término de Toledo) la villa de Vivero al contador mayor. Unos días antes, el 29 de marzo de ese año, tuvo lugar un curioso acontecimiento en la iglesia de San Antón, situada cerca de la ciudad de Toledo: el juramento y pleito-homenaje que, en manos de Juan Pacheco, prestó Alfonso Pérez de Vivero ${ }^{123}$. En ese templo el contador mayor se comprometió a entregar en manos de Alfonso Carrillo, arzobispo de Toledo, la villa de Urueña con su fortaleza, tal como se encontraba cuando se la tomó a Pedro Girón, maestre de Calatrava y señor de esa plaza desde el año 1446.

Las villas de Jorquera, Alcalá del río Júcar, Ves y La Roda cayeron definitivamente en poder de Juan Pacheco el 10 de agosto de $1451^{124}$. Con la incorporación de esas villas puede darse por terminado el largo proceso que había emprendido el hijo de emigrados portugueses desde los años cuarenta del siglo XV para hacerse con el territorio completo del antiguo marquesado de Villena. O casi, porque aún quedaba alguna que otra villa que también había pertenecido a esa jurisdicción. Me refiero a Iniesta, a la que todavía no había podido absorber porque se oponía a ello la decidida voluntad del rey, que había entregado esa plaza hacía ya muchos años a un personaje de su confianza y por quien sentía gran afecto, el mayordomo mayor Ruy Díaz de Mendoza. Pero para Pacheco no existía obstáculo alguno que pudiese impedir consumar su ambición. Y así, y a su debido tiempo, también Iniesta caería en sus garras, y no iba a tardar mucho como inmediatamente veremos.

El pacto de Tordesillas, de febrero de 1451, había sido, como todas, una jornada de ganancias para Juan Pacheco, que esta vez fueron ciertamente cuantiosas, nada menos que cinco villas más para su patrimonio, el oficio de adelantado mayor de Castilla, que de nuevo le había sido confiscado a don Fernando de Sandoval y Rojas, y la confirmación de todos los señoríos de los Portocarrero que habían pertenecido a su esposa ${ }^{125}$. Al mismo tiempo lograba también que el condestable perdonase a los aliados del príncipe, que eran el conde de Benavente y el hijo de Alba. Aunque Toledo regresaba a la obediencia de Juan II, el acuerdo en general era plenamente satisfactorio para

${ }^{123} \mathrm{ADF}$, Catálogo Antiguo, Leg. 5.

${ }^{124}$ Ibídem.

${ }^{125} \mathrm{La}$ confirmación del Adelantamiento en ADF, Catálogo Antiguo, Leg. 9. Y la confirmación de todas las villas que le habían sido confiscadas por el monarca y don Älvaro durante algunos meses en ADF, Catálogo Antiguo, Leg. 56. 
sus intereses, pues conseguía incluso que su hermano Girón recuperase la villa de Urueña que tiempo atrás le había sido tomada por don Álvaro ${ }^{126}$.

La concordia entre Juan II y su hijo duró poco más de un año, hasta el verano de 1452, en que de nuevo surgieron diferencias, pero esta vez el condestable ya no pudo limar las asperezas ${ }^{127}$. Llegó, eso sí, a iniciar negociaciones con Pacheco para recuperar la amistad del príncipe heredero y de aquellos que le apoyaban ${ }^{128}$. Trataba una vez más de neutralizar a los nobles que, como el conde de Plasencia, el de Haro, Benavente y Santillana, intentaban restablecer la Liga nobiliaria a fin de acabar de una vez con el gobierno del valido. Pero en esta ocasión ya no le fue posible atraer a ese aliado, porque nada o casi nada podía ofrecerle, en unos momentos cada vez más delicados en los que, no sólo crecía el número y la importancia de sus enemigos, sino que también el propio monarca se iba apartando progresivamente de su influencia. El final del condestable estaba muy cerca, pero, no obstante, quiero señalar que no entra dentro de mis planes exponer y analizar los graves acontecimientos que se desarrollaron a lo largo del año 1452, y que desembocarían en su ruina y ejecución un año más tarde. Entre otras razones, porque esos hechos pueden fácilmente seguirse a través de los numerosos libros y artículos que el profesor Luís Suárez ha dedicado a esta época tan crítica de la historia del reino castellano y, sobre todo, porque el objetivo que me he propuesto al escribir este trabajo se centra en seguir la trayectoria personal de Juan Pacheco y analizar aquellos acontecimientos que, bien aprovechados por el personaje, le permitirían construir uno de los más sólidos y poderosos patrimonios señoriales de aquella época. Sin duda alguna, Pacheco es un producto casi perfecto de la coyuntura política de su tiempo, y por ello resulta imposible explicar su trayectoria sin tener en cuenta la complejidad de esa misma coyuntura. Es muy posible, por tanto, que el personaje que nos ocupa no hubiese llegado a lo que llegó si hubiese vivido en otro contexto político y en otra época, y es precisamente por ello por lo que me he sentido en la necesidad de analizar aquellos acontecimientos que están en la base de su ascenso político y de su fortuna, ya que supo y pudo aprovecharlos con enorme habilidad para su propio beneficio. En este sentido, los años de 1452, 1453 y 1454 van a presenciar, como siempre, un incremento muy notable de su patrimonio, algo que, por otra parte, venía siendo habitual en su trayectoria desde comienzos de los años cuarenta. A partir de entonces no pasará un solo año sin que, como buen halcón, no arrebatase una o más presas a la Corona, y así procederá hasta el final del reinado de Juan II, y continuará haciéndolo, aún más si cabe, en el de su sucesor, Enrique IV. Por de pronto, en 1452, el monarca, a instancias del príncipe, sigue confirmándole en la posesión de algunas villas que ya le habían sido

\footnotetext{
${ }^{126}$ Luis SuÁREZ FERNÁNDEZ, Los Trastámaras, pp. 205-206.

${ }^{127}$ Ibídem, p. 208.

${ }^{128}$ Ibídem.
} 
concedidas en años anteriores ${ }^{129}$. Ahora se le adjudica también, en perjuicio de los intereses del adelantado de Murcia, la villa de Jumilla, que le venía siendo disputada desde hacia años por este último personaje, pero sobre todo logra incrementar su ya extenso patrimonio con otras dos posesiones, las salinas de Pinilla y la villa de Iniesta ${ }^{130}$. La primera en verdad no le sería difícil incorporarla porque Juan II, presionado por su hijo, le haría donación de esas salinas de Pinillas, Cotillas y Bogarra, situadas en el término de Alcaraz, a fines de noviembre de $1452^{131}$. Estas salinas, que la Corona venía arrendando junto con las toledanas de Espartiñas, constituían un buen negocio para Pacheco porque, al parecer, aunque se tienen escasas noticias, eran muy rentables. Pacheco quedaba obligado por el rey a no hacer innovación alguna en lo que se refería a las condiciones en que estaban arrendadas. Se respetaban, eso sí, los situados que sobre esas salinas había concedido la Corona a otros personajes. De nuevo era el concejo de Alcaraz quién perdía, porque esas salinas formaban parte de su término y de alguna manera se había beneficiado de su explotación.

No satisfecho con tan jugosa concesión, Pacheco solicitó al monarca la donación de Iniesta, pieza que le faltaba, junto con alguna otra, para completar su dominio sobre el territorio del antiguo marquesado de Villena. Pero no le iba a resultar fácil saciar su codicia y hacerse con la villa. Juan II se negó tajantemente a satisfacer esa pretensión porque, entre otras cosas, vulneraba la jurisdicción que sobre esa villa venía ejerciendo desde 1439 su mayordomo mayor, Ruy Díaz de Mendoza, que se oponía también a esa entrega, al menos sin una adecuada compensación. En efecto, Iniesta le había sido concedida por el monarca a Mendoza el 7 de octubre de $1439^{132}$. Unos días más tarde, el 16 de octubre, Juan II le confirma la donación y le hace saber que esa villa formaba parte del marquesado de Villena, señorío que, junto con las villas de Medina del Campo, Aranda de Duero, Roa, Olmedo y Coca, había recibido el príncipe Enrique como dote para su matrimonio con Blanca, la hija del rey de Navarra' ${ }^{133}$. El rey prometía a su hijo que le recompensaría con creces por la renuncia a Iniesta. Poco después el concejo recibía una cédula real en la que se le ordenaba que aceptase como señor a Ruy Díaz de Mendoza. El concejo se opuso decididamente al mandato regio alegando que sus vecinos gozaban de privilegios reales en los que se declaraba expresamente que Iniesta no podía ser dada ni separada de las demás villas

\footnotetext{
${ }^{129} \mathrm{Al}$ parecer, a comienzos de 1452 Alfonso de Aguilar, alcaide de Villanueva de Barcarrota, se había rebelado en esa villa contra Pacheco. Por desgracia ignoramos las causas de esa revuelta, sólo sabemos que se produjo a través de una cédula que Juan II envía al alcaide, el 14 de febrero de 1452, para que de inmediato procediese a entregar la villa a su antiguo señor, y le amenazaba, si se negaba a obedecerle, con darle plenos poderes a Juan Pacheco para que êl mismo con su hueste ocupase la villa por la fuerza de las armas, ADF, Caja $3, n^{0} 3$. Se le confirma también la donación de las Peñas de San Pedro; ADF, Caja 3, n⿳⺈ 2 .

${ }^{130}$ Sobre Jumilla ADF, Caja $129, \mathrm{n}^{\circ} 1$.

${ }^{131} \mathrm{ADF}$, Caja 3, n ${ }^{\circ} 4$.

${ }^{132} \mathrm{ADF}$, Catálogo Antiguo, Leg. 56. El monarca había prometido a Ruy Díaz de Mendoza la donación de 500 vasallos.

${ }^{133}$ Ibídem.
} 
que pertenecían al marquesado de Villena "no dividiendo ni apartando vn lugar de otro, e lo qual está jurado de guardar por el dicho sennor rey" 134 . Por otra parte, continuaban afirmando los oficiales del concejo, "esta villa junto con el dicho marquesado fue dada e entregada a nuestro sennor el rey don Juan de Navarra, al qual tenemos jurado por sennor e prestado fidelidad e obediençia por ciertos annos los quales no son conplidos". Se oponían, por tanto, a entregar la villa al mayordomo mayor del rey, "ni los ofiçios ni ejercicios della ni los derechos y rentas, fasta que el rey Juan de Navarra expresamente por su carta nos soltase el juramento y fidelidad que le prestamos". En todo caso, concluían, sólo cederían en su actitud si la donación se hiciese a "persona de casa real". Es indudable que los argumentos expuestos por el concejo de Iniesta eran verdaderos, porque, en los acuerdos que se tomaron en el tratado de Toledo en 1436, se le adjudicó el marquesado de Villena al rey Juan de Navarra, para que lo administrase y gobernase hasta el momento en que su hija Blanca contrajese matrimonio con el heredero del trono de Castilla, y sólo después de celebrados los esponsales es que quedaría bajo el poder del príncipe Enrique ${ }^{135}$.

La negativa de la villa a reconocer a Ruy Díaz de Mendoza como señor duró más de cuatro meses. Los enviados de Juan II para reducir al concejo y obligarle a recibir como señor al mayordomo mayor nada consiguieron. Se les hizo saber entonces que en el reino había un poder superior al de Juan de Navarra, poder que correspondía al rey que podía utilizarlo con total libertad "para faser de la dicha villa e de todas las otras çibdades e villas de sus regnos lo que a su sennoría pluguiese". Era el famoso concepto del "poderio real absoluto del que quiero vsar e vso" que esta vez se quiso resaltar para reducir la oposición de la villa. Se les comunicó también que el propio príncipe de Asturias, a quien de hecho pertenecía Iniesta, había aceptado la donación real a Ruy Díaz. Aún así, ni uno ni otro argumento hicieron mella en el concejo de la villa. Finalmente, no les quedó más remedio que ceder, pero antes hubo que presentar al concejo la renuncia de Juan de Navarra al señorío de la villa y su aceptación como señor de Ruy Díaz de Mendoza ${ }^{136}$. El rey de Navarra, en unos momentos especialmente delicados para su política en la dura pugna que sostenía con el condestable por la conquista del poder, sacrificó al concejo de Iniesta para salvaguardar sus intereses políticos.

De esta manera, Iniesta pasaba a poder del mayordomo mayor de Juan II. La villa, como había sucedido muchas veces en el pasado y continuaría pasando en el futuro, fue una víctima de la lucha por el control del reino entre los infantes de Aragón y don Álvaro de Luna. A regañadientes, porque en su concejo había muchos partidarios de Juan de Navarra, la villa se dispuso a

\footnotetext{
${ }^{134}$ Ibídem.

${ }^{135}$ Ibídem. Sobre el tratado de Toledo de 1436 ver Luis SuÁREZ FERnÁndEZ, Los Trastámaras.

${ }^{136}$ Ibídem. La carta de Juan de Navarra aceptando la donación de Iniesta a Ruy Díaz de Mendoza va fechada en Madrigal el 23 de febrero de 1440.
} 
recibir al nuevo señor y a llevar a cabo la simbólica ceremonia de toma de posesión, que tuvo lugar el 26 de febrero de 1440. Antes, sin embargo, se le obligó a prestar juramento de que respetaría una serie de privilegios que la villa poseía desde siempre. En primer lugar las libertades, franquezas y privilegios que tenía. Después le exigieron que se abstuviese de nombrar a los oficiales del cabildo concejil, competencia esta que desde la época del marqués don Enrique de Aragón correspondía a los vecinos de la villa y no al señor. Así mismo, no podría nombrar corregidor ni tampoco procurador a no ser que la villa se lo pidiese. Los vecinos serían juzgados por sus delitos en la propia villa; así se le impuso que en adelante "no sea sacado ningún vecino de la villa por prisión o por lo levar a otra parte fuera della, saluo que el que delinquere que sea punido en esta villa por el tal delito que cometiere, que sea preso e detenido en ella por la debda y no sea sacado fuera de la jurisdicción de la villa". Finalmente, Ruy Díaz se comprometió a que la escribanía formase parte de los bienes de propios del concejo, y a que el alcalde mayor sólo tuviese competencias en las apelaciones o "agravios que hagan remisión de todas las penas así civiles commo criminales en que fasta el día de oy aya incurrido el conçejo, commo otra cualquier persona, e las non demandáredes". Tras jurar que respetaría todas estas exigencias que sus nuevos vasallos le presentaban, se le dio posesión de la villa. De esta manera, la oligarquía que controlaba el concejo de Iniesta, tras el pacto con el nuevo señor, que se veía obligado a respetar las condiciones impuestas, garantizaba su autonomía y sus propios intereses. Desde entonces la villa se había mantenido bajo el poder de Ruy Díaz de Mendoza.

La reiterada negativa de Juan II a ceder a las pretensiones de Pacheco de hacerse con Iniesta obligaría a éste a buscar otros procedimientos que pudiesen permitirle incorporar la villa a sus dominios. Recurrió entonces al trueque, y así ofreció a Ruy Díaz de Mendoza la villa de Castrojeriz por la de Iniesta. El mayordomo mayor pensó que podría interesarle la oferta. Así, se llegaría a un primer acuerdo, el 15 de noviembre de 1452, por el que ambos personajes aprobaban y ratificaban el canje de Iniesta por Castrojeriz ${ }^{137}$. Se nombraron entonces a dos jueces árbitros, Diego de Provaño y Juan de Soto, para que procediesen a realizar un censo de todos los vecinos que habitaban en ambas villas, y averiguasen también el valor y la calidad de las rentas que pagaban a sus respectivos señores ${ }^{138}$. Juan de Soto, que representaba a Ruy Díaz de Mendoza, y Pedro Bañón al marqués de Villena, procedieron a hacer

${ }^{137}$ ADF, Catálogo Antiguo, Leg. 42, n ${ }^{\circ}$ 4. En uno de los capítulos firmados para el trueque Ruy Díaz cedía también a Pacheco un juro de 41.000 mrs. situados sobre las rentas reales de la villa de Requena. A cambio, el marques de Villena le prometía darle otro por un valor similar y que situaría no sobre la villa de Castrojeriz sino en las rentas de los pueblos de su merindad. Cada vasallo se valoró en la cantidad de $4.000 \mathrm{mrs}$. El príncipe, Villena y Girón se comprometieron a no devolver jamás la villa de Castrojeriz a Diego Gómez de Sandoval. Estas eran las garantías que exigía Ruy Díaz que temía, con fundamento, que si los partidarios del rey de Navarra eran perdonados algún día, podía suceder que se viese obligado a cederle esa villa y, de esa manera, perderlo todo. Don Enrique y los dos hermanos le prometían protección y tratarían de procurarle alguna nueva prebenda por parte del rey. Ruy Díaz les prometió a su vez amistad y ayuda.

${ }^{138}$ ADF, Catálogo Antiguo, Leg. 42, no 4 y Leg. 56, no 5. 
recuento de los vecinos de Iniesta. El padrón, que redactaron el 9 de diciembre de 1452 , arrojaba un total de 370 vecinos, lo que mostraba de manera bien clara que la villa se hallaba muy bien poblada y, en consecuencia, los tributos y rentas que debían pagar debían ser bastante jugosos ${ }^{139}$. Por lo que se refiere a Castrojeriz conocemos bien, además del número de vecinos, la fiscalidad y las diversas modalidades de rentas que Juan Pacheco había impuesto en la villa tras perderla el conde Diego Gómez de Sandoval. Un cuadernillo fechado el 14 de diciembre de 1448 describe la situación en que se hallaba Castrojeriz de la siguiente manera ${ }^{140}$ :

-entre Castrojeriz y los pueblos de Villasmalo y Astudillo se contabilizaron un total de 551 vecinos, entre pecheros e hidalgos, y 55 clérigos.

-la villa tenía diez barrios: el de Tanara, y los de Bárcena -que era por cierto el más poblado-, Vallejo, San Esteban, Santiago, Santo Domingo, Barruelo, Barladán, San Antón y Santa María.

-las rentas que pagaba la villa al señor eran las siguientes:

a) el pedido: $14.000 \mathrm{mrs}$.

b) la martiniega: $2.800 \mathrm{mrs}$.

c) la escribanía: $4.800 \mathrm{mrs}$.

d) el yantar: $1.200 \mathrm{mrs}$.

Castrojeriz formaba una merindad que llevaba el nombre de la villa principal. Las villas y lugares que la integraban eran las siguientes:

- Villaquerán. Se hallaba próxima a Castrojeriz, tenía dos vecinos y era un lugar solariego del mariscal Pedro García

-Yudego y Villondiego. Se trataba de un concejo de behetría, lo habitaban 45 vecinos.

-Castellanos. Era un lugar solariego perteneciente a la jurisdicción del Hospital del Rey. Tenía trece vecinos.

-Fotanás. Era abadengo del obispo de Burgos. Tenía 35 vecinos.

-Palazuelos. Se hallaba próximo a Pampliega. Era un lugar de behetría, tenía dos vecinos.

- Villasmalo. Lugar solariego del almirante, que se lo había concedido a Jofre, su maestresala. Contaba con dos vecinos.

-Villodrigón. Lugar de behetría, lo habitaban tres escuderos.

-Revilla. Próximo al lugar de Vallijera. Pertenecía a la jurisdicción del príncipe de Asturias y contaba con ochenta vecinos.

- Villamediana. Lugar de behetría, contaba con doce vecinos. vecinos.

-Vallijera. Solariego de doña Juana de Quesada, sólo tenía dos

-Cordobilla. Behetría de doce vecinos.

\footnotetext{
${ }^{139}$ Ibídem. El padrón de vecinos fue redactado por Juan de Soto en nombre de Ruy Díaz de Mendoza. En 1456 las rentas que pagaban los vecinos de la villa eran las siguientes: a) La escribanía pública: $4.000 \mathrm{mrs}$; b) la cueva de la sal, su portazgo y el portazgo de la villa, 25.000 mrs.; c) el tributo ordinario: $40.000 \mathrm{mrs}$. El concejo arrendaba cada año una huerta al señor por

${ }^{140}$ ADF, Catálogo Antiguo, Leg. 42, no 3.
} 
- Villalaco. Behetría de doce vecinos.

- Balbuena del río Pisuerga. Behetría de doce vecinos.

-San Cebrián de Buena Madre. Lugar perteneciente a la jurisdicción del abad de Santillana. Tenía doce vecinos.

-Pedrosa de Socastro. Behetría de setenta vecinos. ocho vecinos.

- Henestrosa. Lugar solariego del mariscal Pedro García. Lo habitaban tres vecinos.

Hitero del Castillo. Es un lugar solariego del conde de Haro. Tenía vecinos.

-La Puente de Hitero. Lugar de behetría. Contaba con cuarenta

- Hitero de la Vega. Lugar de behetría. Contaba con ochenta vecinos.

-Llantadilla. Lugar de behetría. Contaba con ciento cincuenta vecinos.

- Palacios del río Pisuerga. Lugar solariego. Tenía veinte vecinos. un vecino.

-Santolla del Término. Lugar abadengo del obispo de Burgos. Tenía

-Arenillas del río Pisuerga. Lugar de behetría. Contaba con ciento veinte vecinos.

-Zorita de río Pisuerga. Lugar de behetría. Contaba con cinco vecinos.

- Padilla de Suso. Lugar de behetría. Contaba con ochenta vecinos. vecinos.

-Padilla de Yuso. Lugar de behetría. Contaba con ciento veinte

-Grijalva. Lugar de behetría. Tenía noventa vecinos.

- Villiegas. Lugar de behetría. Tenía noventa vecinos. vecinos.

- Villoveta. Lugar solariego de Juan de Padilla. Contaba con cuarenta cinco vecinos.

- Villasidrio. Lugar solariego del Hospital del Rey. Tenía treinta y

- Villamorón. Lugar de behetría. Contaba con quince vecinos.

- Olmillos. Lugar solariego de Pedro de Cartagena. Contaba con sesenta vecinos.

-Perej. Lugar solariego del mariscal Pedro García. Contaba con dos vecinos.

-Castril de Murcia. Lugar de behetría. Tenía sesenta vecinos.

- Villasilos. Lugar de behetría. Contaba con setenta vecinos.

-Torre, cerca de Astudillo. Lugar solariego del obispo de Palencia. Tenía quince vecinos.

- Melgar de Yuso. Lugar de behetría. Tenía quince vecinos.

-Villodre. Lugar de behetría. Contaba con quince vecinos.

-Espinosa de Baldelmos. Lugar de abadengo del monasterio de Frómista. Tenía dos vecinos.

-Santoyo. Lugar de behetría. Tenía ciento cincuenta vecinos.

-Santiago del Val. Lugar de abadengo del monasterio de San Isidro, que estaba cerca de Dueñas. 
-Palacios del Alcor. Lugar solariego del obispo de Palencia. Tenía treinta y cinco vecinos. vecinos.

-Bobadilla del Camino. Lugar de behetría. Contaba con ciento treinta

\section{Páramos}

-Pedrosa del Páramo. Lugar de behetría. Contaba con veinte vecinos.

-Sosinos. Lugar de behetría. Contaba con quince vecinos.

- Masiles. Lugar de behetría. Contaba con quince vecinos.

- Tovar. Lugar solariego de Sancho de Tovar. Tenía veinte vecinos.

-Las Ormazas. Villa solariega de Alonso de Silva. Contaba con sesenta vecinos. vecinos

-Quintanilla de Per Abarca. Lugar de behetría. Contaba con doce

-San Pantaleones. Lugar de behetría. Contaba con tres vecinos.

-Ruyales. Lugar de behetría. Contaba con doce vecinos.

-Temellos. Lugar de behetría. Tenía treinta y cinco vecinos.

-Monesteruelo. Lugar de behetría. Tenía dos vecinos.

-Santiváñes. Villa de behetría. Tenía setenta vecinos.

- Huermeses. Lugar de behetría. Tenía treinta vecinos.

-Rohos. Lugar de behetría. Contaba con veintiséis vecinos.

- Celadas. Lugar de behetría. Tenía treinta vecinos.

- Minón. Lugar de behetría. Tenía diez vecinos.

-La Nuez de Río Durbeles. Lugar de abadengo del monasterio de Oña.

Tenía cuarenta vecinos.

-Mansilla. Lugar solariego de Ferrán Sarmiento.

-Zumel. Lugar de behetría. Tenía diez vecinos.

-Rebolledes. Lugar de behetría. Contaba con diez vecinos.

-Lodeso. Lugar de behetría. Contaba con diez vecinos.

- Santa María de Tajadura. Lugar de behetría. Tenía quince vecinos.

-Tajadura. Lugar yermo. No hay vecinos.

-Pedrosa del río de Urbel. Lugar de behetría. Contaba con dieciocho vecinos.

-Quintanaseca. Lugar de behetría. Contaba con tres vecinos.

- Avellanusa. Lugar de behetría. Tenía veinticinco vecinos.

-San Pedro Simuel. Lugar de behetría. Tenía doce vecinos.

- Villorejo. Lugar de behetría. Tenía treinta vecinos.

-Palacios de Benafiel. Lugar solariego del monasterio del mismo nombre. Tenía veinte vecinos.

- Villanueva de Garahano. Lugar solariego del conde de Castañeda. Contaba con doce vecinos.

-Estar. Lugar solariego del conde de Castañeda. Contaba con veintidós vecinos.

-Acentores. Lugar de behetría. Contaba con veinticinco vecinos.

-Sanisar de Benafiel. Lugar de behetría. Tenía quince vecinos. 


\section{Xuarros}

-Santa Cruz. Lugar solariego del abad de San Pedro. Contaba con cincuenta vecinos.

-Espinosa Costorrica. Solariego del abad de San Pedro. Tenía dos vecinos.

-Yuca. Lugar de behetría. Contaba con seis vecinos. vecinos.

-Mozoncillo. Lugar solariego de Pedro Sarmiento. Tenía ocho

-Hontoria de la Cantera. Lugar de behetría. Tenía veinte vecinos.

-Hontoruela. Aldea yerma. diez vecinos.

-Brijeda con la Asenán. Lugar de la abadesa de las Huelgas. Tenía

-Medina de San Cebrián. Lugar de abadengo de San Pedro de Arlanza. Tenía diez vecinos.

-San Urián. Lugar de behetría. Tenía diez vecinos.

- Villoniel. Lugar solariego de Pedro Sarmiento.

- Cubiel de la Cesa. Abadengo del obispo de Burgos. Contaba con cinco vecinos.

-San Andrés de Juarros. Lugar perteneciente a la jurisdicción del abad de San Pedro de Arlanza. Tenía ocho vecinos. veinte vecinos.

-Revilla del Campo. Lugar solariego del obispo de Burgos. Tenía

-Revilla de la Fuente. Lugar despoblado.

- Palazuelos de la Sierra. Perteneciente a la jurisdicción de la abadesa de las Huelgas de Burgos. Lo habitaban diez vecinos.

-Salguero de Muera. Lugar solariego de Pedro Sarmiento. Contaba con ocho vecinos.

-Usines. Abadengo del obispo de Burgos. Tenía treinta vecinos. vecinos.

-Revilla Herrus. Solariego del obispo de Burgos. Tenía treinta y cinco

-San Cristóbal de Yuecas. Sólo tenía un vecino.

-Cueva de Juarros. Lugar solariego de los herederos de Juan Carrillo de Badeormasa. Tenía cinco vecinos.

-Salguero del Salse con Bujedo y la Aldeyuela. Los tres eran solariegos. Tenían tres vecinos. vecinos.

-San Millán. Lugar solariego de Pedro Sarmiento. Contaba con diez vecinos.

-Cubiel del Campo. Solariego del obispo de Burgos. Tenía veinte vecinos.

-Cuevas de San Clemente. Solariego del obispo de Burgos. Tenía diez

-San Tirso. Solariego, contaba con un solo vecino.

El trueque de Iniesta por Castrojeriz favorecía, al parecer, a Ruy Díaz de Mendoza, pues la segunda contaba con más vecinos que la primera. En 
cualquier caso el canje se llevó a cabo a comienzos de diciembre de 1452 . Así, el 3 de diciembre de ese año el criado de Pacheco, Diego de Provaño, en nombre de su señor, tomaba posesión de Iniesta, prometiendo a su concejo que respetaría y guardaría todos los privilegios y libertades que tenían desde los tiempos del marqués don Alfonso de Aragón, hijo del infante don Pedro ${ }^{141}$. Unos días más tarde, Ruy Díaz de Mendoza, hacía lo propio con Castrojeriz $^{142}$. Y, sin embargo, unos meses más tarde, el mayordomo mayor de Juan II comenzó a experimentar ciertas dudas sobre si el canje le podría o no beneficiar. El problema, al parecer, radicaba en la fiscalidad que, según Mendoza, le perjudicaba, ya que las rentas de Iniesta eran más elevadas que las de Castrojeriz, una villa, ciertamente muy poblada de hidalgos. El hecho cierto es que ambos señores decidieron prorrogar el plazo a fin de que los compromisarios volviesen a reunirse, iniciar un nuevo recuento de vasallos y de rentas y determinar, finalmente, el valor de ambas villas ${ }^{143}$. Se llegaría incluso a nombrar nuevos árbitros, porque Mendoza desconfiaba de Pacheco y temía que pudiese engañarle comprando la voluntad de alguno de los compromisarios. Al final se acordó el nombramiento de Gutierre de Fuensalida, Diego de Provaño y Lope de Mendoza que, finalmente, en octubre de 1453 , determinaron que el trueque se llevase a efecto porque beneficiaba a ambas partes ${ }^{144}$. De esta manera Iniesta pasaba a poder de Pacheco y Castrojeriz a Ruy Díaz de Mendoza.

Faltaba aún otra pieza para completar el cerco a las villas del antiguo marquesado. Esta vez se trataba de Villarrobledo. Esta villa había formado parte también del extenso alfoz del concejo de Alcaraz, que desde comienzos de los años cuarenta estaba siendo despojada de sus términos para satisfacer las ambiciones de algunos nobles próximos al monarca y al príncipe de Asturias. El más beneficiado por este injusto despojo había sido, como sabemos, Juan Pacheco que había recibido Lozuza, Munera, El Bonillo, Villanueva de Alcaraz y las salinas de Pinilla, Cotillas y Bogarra. Pero hubo otros que también sacaron tajada de esa enajenación. En concreto, el conde de Paredes de Nava, Rodrigo Manrique, a quien se le había hecho merced de Villarrobledo que, por entonces, en los años cuarenta del siglo XV se llamaba Robledillo. Don Rodrigo, al recibir esta aldea de Alcaraz, que de inmediato fue separada de su jurisdicción, le concedió el título de villa y le cambió el nombre por el de Villarrobledo ${ }^{145}$. Fue mucho después, a comienzos de los años cincuenta, cuando el marqués de Villena entró en tratos con el conde de Paredes para proponerle un trueque similar al que había hecho con Ruy Díaz de Mendoza. Don Rodrigo no aceptó esa proposición, pero en cambio si le

${ }^{141} \mathrm{ADF}$, Catálogo Antiguo, Leg. 42, números 3 y 4.

${ }^{142} \mathrm{ADF}$, Catálogo Antiguo, Leg. 42, números 3 y 4.

${ }^{143} \mathrm{ADF}$, Catálogo Antiguo, Leg. 51, no 3. Ruy Díaz de Mendoza llegó incluso a solicitar del monarca nueva confirmacion de la donación de Iniesta. Juan II así lo hizo el 20 de diciembre de 1452; ADF, Caja 3, $n^{\circ} 5$.

${ }^{144} \mathrm{ADF}$, Caja $3, \mathrm{n}^{\mathrm{o}} 5$.

${ }^{145} \mathrm{ADF}$, Caja $3, \mathrm{n}^{\mathrm{0}} 6$. 
hizo saber que podría estar dispuesto a venderle la villa si le ofrecía por ella un buen precio. Pacheco, decidido a hacerse con Villarrobledo a cualquier precio, pensó entonces en vender alguna de las villas que se hallaban más alejadas del centro principal de sus dominios, y que por ello mismo y por otras razones podrían suscitarle problemas. La elegida para la enajenación fue Salvatierra, una de las tres villas del sur de Extremadura que le habían sido concedidas en 1444, y de las que no llegaría a tomar posesión hasta un año más tarde ${ }^{146}$. Los intereses de Villena coincidían con los del personaje más poderoso de esa zona extremeña que, como sabemos, había sido el causante principal de que Pacheco tuviese muchas dificultades para hacerse con esas villas $^{147}$. Se trataba del conde de Feria, don Lorenzo Suárez de Figueroa, a quien molestaba profundamente la presencia, en zonas territoriales que consideraba de su exclusiva competencia, de un poder tan ambicioso e intrigante como el que representaba el privado del príncipe de Asturias. Pacheco, sabiendo el interés de don Lorenzo por redondear sus posesiones de Feria y Zafra con la incorporación, a ser posible y por cualquier medio de esas tres villas, le propuso entonces la compra de Salvatierra. La venta fue rápida. El 12 de octubre de 1453 don Lorenzo Suárez de Figueroa compraba a Pacheco esa villa por 12.000 doblas $^{148}$. Sin embargo, al final, don Lorenzo se echó atrás y la venta no se llegó a realizar. Pacheco, sin embargo, pudo comprar Villarrobledo a don Rodrigo Manrique. Y así, el 4 de agosto de 1454 Villarrobledo caía en su poder por $500.000 \mathrm{mrs}$. que entregó al conde de Paredes $^{149}$. De esa manera redondeaba y daba homogeneidad a sus dominios $\mathrm{y}$, al mismo tiempo, cercaba a la ciudad de Alcaraz por la que desde el comienzo de su carrera sentía un gran interés y de la que esperaba pacientemente que con el tiempo, y a través de todas esas operaciones ya señaladas, cayera bajo su dominio.

Con la incorporación de Iniesta y la compra de Villarrobledo puede decirse que Pacheco había cerrado la etapa más difícil de su vida. El marquesado de Villena, el primero y el más importante de sus objetivos iniciales a conseguir, largamente acariciado desde los comienzos de su carrera política, que había comenzado en los primeros años de la década de los cuarenta, ya era enteramente suyo. A la muerte de Juan II, en 1454, se había convertido en uno de los más poderosos y ricos hombres de Castilla. La ejecución de don Álvaro de Luna, la desaparición del rey y el advenimiento al trono de su gran protector, Enrique IV, la persona a quien debía todo lo que era y todo lo que poseía, le iban a proporcionar no sólo más señoríos para satisfacer su insaciable codicia, sino también llegar a controlar y monopolizar en su propio beneficio el gobierno del reino de Castilla. La fortuna le sonreía,

\footnotetext{
${ }^{146} \mathrm{He}$ estudiado esta época en un trabajo aún inédito que lleva por título Juan Pacheco. De doncel del príncipe de Asturias a marqués de Villena (1440-1445).

${ }^{147}$ Ibídem.

${ }^{148}$ La noticia de la venta de Salvatierra en el libro conservado en el ADF, Noticia de todos los lugares de que se componen los Estados de Villena....

${ }^{149} \mathrm{La}$ venta de Villarrobledo en ADF, Caja $3, \mathrm{n}^{\circ} 6$.
} 
estaba en la plenitud de su vida y se preparaba con entusiasmo para ejercer el poder porque se sabía imprescindible para el nuevo monarca. El futuro, en suma, era suyo. 


\section{APÉNDICE DOCUMENTAL}

1448, septiembre, 25. Aranda.

El príncipe Enrique concede la villa de Moya a Juan Pacheco.

ADF, Catálogo Antiguo, Leg. $4 \mathrm{n}^{\circ} 16$

B. Publicado en José Manuel NiETo Soria (Director), Orígenes de la Monarquía Hispánica: Propaganda y Legitimación. (CA. 1400-1520). Madrid, Dykinson, 1999, pp. 494-495.

Don Enrrique por la gracia de Dios prinçipe de Asturias, fijo primogénito heredero del muy alto e muy esclaresçido príncipe Rey e sennor mi sennor e padre el Rey don Juan de Castilla e de León, acatando los muchos buenos e leales serviçios que vos don Juan Pacheco, marqués de Villena, mi mayordomo mayor, me auedes fecho e fasedes de cada día e en alguna emienda e remuneraçión de ellos fago vos merçed graçia e donaçión de la mi villa de Moya e su tierra e con la juridiçión e justiçia çevill e criminal alta e baxa e mero e misto imperio e rentas e pechos e derechos e penas e calonnas e con todos sus términos e tierras e territorios e destritos prados e pastos e montes e ríos e aguas corrientes estantes e manantes e con todas las rentas e pechos e derechos e otras cosas pertenesçientes al sennorio de la dicha villa e con todas sus entradas e salidas e con todas las otras pertenençias quantas ha e debe aver e le pertenesçen e pertenesçer deven en qualquier manera e por qualquier razón asy de fecho como de uso e costumbre e fuero e derecho. La qual dicha merçed e graçia e donaçión vos yo fago de la dicha villa e su tierra con todas sus pertençias como dicho es para que de aquí adelante la ayades para vos e para vuestros herederos e suçesores después de vos por juro de heredad para siempre jamás, e para que la podades vender e empennar, dar e donar trocar e cambiar e enajenar e faser della e en ella como cosa vuestra propia libre e desembargada tanto que lo non podades faser ni fagades con iglesia ni monesterio ni con persona de orden ni de religión ni de fuera de los regnos e sennorios del dicho rey mi sennor syn su liçençia e mandado quedando ende para el dicho rey mi sennor e para los reyes que después dél fueren alcavalas e terçias e pedidos e monedas e mineras de oro e de plata e de otros metales e la mayoría de la justiçia e las otras cosas que pertenesçen al soberano sennorio real e se non pueden apartar dél. E por esta mi carta e con ella e por la tradiçión que della vos fago la qual vos do e enrego por posesión e en nombre de posesión vos do e traspaso la tenençia e posesión real corporal e benal e çevill e natural de la dicha villa e su tierra con todo lo suso dicho e la propiedad e sennorio de todo ello e de cada cosa e parte de ello e vos do abtoridad e facultad e poderío para la entrar e tomar e vos apoderar de ella e mando al conçejo, alcaldes, alguazil, regidores, cavalleros, escuderos e omes buenos de la dicha villa de Moya a vezinos e moradores de ella e su tierra e a cada uno de ellos que vos ayan e reçiban por su sennor e de la dicha villa de Moya e de su tierra e vos exiban e fagan e guarden la reuerençia e obediençia e subjeçión e fidelidad e pleito e omenaje e juramento e todas las otras cosas e cada una de ellas que vasallos 
solariegos deven e son tenudos a su señor, e consientan usar a vos e a quien vuestro poder oviere de la dicha justiçia e jurisdiçión çevill e criminal alta e baxa e mero misto inperio de la dicha villa e su tierra e vos recudan e fagan recodir con todas las rentas e pechos e derechos e penas e calonnas e otras qualesquier cosas pertenesçientes al sennorio de la dicha villa e su tierra e que vos no pongan ni consientan poner en ello ni en parte dello embargo ni contrario alguno. E los unos ni los otros non fagan ende al so pena de la mi merçed e de privaçión de los ofiçios e confiscaçión de todos sus bienes a cada uno por quien fincar de lo asy fazer e complir para la mi cámara e demás mando al omme que les esta mi carta mostrare que los emplase que parescan ante mi doquier que yo sea del día que los emplasare fasta quinze días primeros siguientes so la dicha pena a cada uno so la qual mando a qualquier escriuano público que para esto fuere llamado que de ende al que la mostrare testimonio signado con su signo por que yo sepa en commo se cumple mi mandado. Dada en la my villa de Aranda veynte e çinco días de setiembre anno del nasçimiento del nuestro sennor Ihesu Christo de mill e quatroçientos e quarenta e ocho años.

Yo el prínçipe (rubricado).

Yo Alfonso Gonzalez de la Hoz, secretario de nuestro sennor el prínçipe la fize escreuir por su mandado.

1448, octubre, 20.

Juan II concede la villa del Barco de Ávila a Juan Pacheco.

ADF, Caja 2, $n^{\circ} 24$

Don Johán por la gracia de dios rey de Castilla, de León, de Toledo, de Gallisia, de Seuilla, de Córdoua, de Murçia, de Jahén, del Algarabe, de Algesira, e sennor de Viscaya e de Molina. Por quanto yo con acuerdo del prínçipe don Enrique, mi muy caro e muy amado fijo, e él junto conmigo por los muchos e graues e enormes casos, crímines, delictos e cosas cometidos asy contra mi persona e contra la corona real commo contra el bién e pró común de mis regnos que son públicas, notorias e conosçidas e yo por tales las he e declaro mandé prender a los condes de Benavente e de Alua e don Enrique, hermano del almirante don Fradique, e a Pedro de Quiñónes e a Suero de Quiñones, su hermano, e les mandé entrar e tomar e apoderar para mí todas sus villas e lugares, tierras, castillos e fortalesas e otros sus bienes e heredamientos asy muebles commo rayses, e otrosy todas e qualesquier merçedes que ellos en qualquier manera de mí avian e tenian en mis libros, e otrosy por todas aquellas mesmas causas e rasones, las quales así mesmo son públicas, notorias e conosçidas e yo por tales las hé e declaro, e por algunas otras e legítimas causas que a ello me mouieron mandé entrar e tomar e apoderar para mí todas las villas, lugares, tierras, castillos e fortalesas e otros bienes e heredamientos muebles e rayses, e asy mesmo otras quales quier merçedes que el almirante don Fradique e don Diego Gómes de Sandoual, conde de Castro, e Johán de Touar, mi guarda mayor, e don Fernando de Rojas, mi adelantado mayor de Castilla, e don Diego, su hermano, fijos del dicho conde de Castro, e cada vno dellos tenían e avían de mí en mis libros e fuera dellos en los dichos mis regnos e sennoríos, las quales dichas villas e lugares, tierras, castillos e fortalesas e otros sus bienes e heredamientos de todos los suso dichos e de cada vno dellos asy muebles commo rayses e merçedes susodichas por los dichos 
casos e crímines e delictos por ellos e por cada vno dellos cometidos por el mesmo fecho los sobredichos condes de Benavente e de Alua o don Enrique, hermano del dicho almirante, e Pedro de Quiñones e Suero de Quiñones, su hermano, e almirante don Fradique e don Diego Gómes de Sandoual, conde de Castro, e Johán de Touar e don Fernando de Rojas e don diego, su hermano, e cada vno dellos perdieron e son e deuen ser confiscados e aplicados a la mi cámara e fisco, e yo por la presente a mayor abondamiento por las cosas asy por ellos cometidas e perpetradas e por otras legítimas justas causas que a ello me mueuen, sy neçesario es de mi çierta çiençia e poderío real absoluto supliendo qualquier defecto asy de sustançia commo de solepnidad que de derecho se requieran e commo en cosas e por cosas notorias e por tales por mí conosçidas e declaradas, commo rey e sennor non conosçiendo superior declaro ellos e cada vno dellos aver perdido los dichos bienes e todo lo suso dicho e cada cosa e parte dello e los confisco e aplico e he por confiscados e aplicados para la mi cámara e fisco, e quiero e mando que de aquí adelante non sean avidos por sennores de cosa alguna dello. E commo de cosa mía propia e por mi poseyda acatando los muchos e buenos e leales e sennalados seruiçios que vos don Juan Pacheco, marqués de Villena, mayordomo mayor del dicho prínçipe mi hijo, e del mi consejo me auedes fecho e fasedes de cada día e los muchos peligros a que por mi seruiçio vos avedes puesto e en que vos avedes visto e por el bién e pró común de mis regnos e de la corona real dellos, lo qual todo es a mí bien notorio e conosçido e por tales hé e declaro los dichos vuestros seruiçios, e quiero e es mi merçed que en algund tienpo non sean traydos aprueua, e de mi propia e libre voluntad e en alguna emienda e remuneraçión dellos fago vos merçed e graçia e donaçión pura e perfecta e non reuocable que es dicha entre biuos por juro de heredat para sienpre jamás para vos e para vuestros herederos e subçesores e para aquél o aquellos que de usos o dellos ouieren causa para vender e enpenar, donar, trocar e traspasar e enajenar e faser en todo e en parte dello commo de cosa vuestra propia, libre e quita tanto que non sea con eglesia nin monesterio nin onbre nin otra persona de orden nin de religion nin de fuera de mis regnos syn mi espeçial liçençia e mandado de la villa del Barco de Avila con su castillo e fortalesa e con todas sus aldeas, tierras, término e territorios e destritos, montes e prados e dehesas e rios e aguas corrientes e manantes e estantes, e con todos los vasallos asy xristianos commo moros e judios que agora ay e biuen e moran e ouieren e vinieren e morar en de aquí adelante en la dicha villa e su tierra e términos e aldeas e con todas e quales quier heredades e casas e asennas e molinos e bienes rayses que el dicho conde de Alua auía e tenía e le pertenesçía e pertenesçer deuia en la dicha villa del Barco de Avila e su tierra e términos e aldeas e en cada vna e qualquier dellas, e con la jurediçión e justiçia çeuil e criminal alta e baxa e mero e misto ynperio de la dicha villa e su tierra e términos e aldeas e de todos los otros lugares de la jurediçión de la dicha villa e que fasta aquí han andado e andan con la jurediçión de la dicha villa, segund e por la forma e manera que la tenía el dicho conde Dalua, e otrosy con todos los pechos e derechos asy portadgo e escriuanía, martiniega, yantar, ynfurçiones, penas e calopnnas e omesillos commo otros qualesquier derechos pertenesçientes al sennorío de la dicha villa e su tierra, e con todas las heredades, casas, bodegas e asennas e molinos e otros qualesquier bienes que él en la dicha villa e su tierra e en los lugares de su jurediçión tenía e avia avido por conpras e donaçiones o troques o en otra qualquier manera. E otrosy con todas qualesquier rentas de pan e vino e carne e dineros e otras quales quier cosas que el dicho conde de Alua auía e tenía en la dicha villa e su tierra de juro de heredad e con todo lo otro poco o mucho que en la dicha villa e su tierra e jurediçión tenía e avía e le pertenesçía e pertenesçer deuía commo quier e en qual quier manera quedando para mí e para los reys que después de mi vinieren alcaualas e pedidos e monedas asy 
foreras commo las otras monedas que yo e los otros reys que después de mi vinieren mandaremos derramar e cojer en los dichos mis regnos, e otrosy mineras de oro e de plata $\mathrm{i}$ otros metales e la superioridad de la justiçia e las otras cosas que se non pueden nin deuen apartar del sennorío real, de la qual dicha villa con su castillo e fortalesa e vasallos con sus términos e jurediçión e pechos e derechos e otras rentas e con todo lo suso dicho e qual quier cosa e parte dello vos fago la dicha merced por juro de heredad para sienpre jamás para vos e para los dichos vuestros herederos e subçesores e para aquél o aquellos que de vos o dellos ouieren causa commo dicho es, non enbargante que ante de agora yo della tenía fecha merçed a otra qualquier persona o de qualquier cosa o parte de lo que dicho es, que yo por la presente del dicho mi propio motuo e çierta çiençia e poderío real absoluto de que en esta parte quiero vsar e vso reuoco la tal merçed e quiero que sea en sy ninguna e de ningún valor e efecto, e otrosy non enbargante qualquier derecho vos e acçión o demanda que yo e mis herederos e subçesores ayan o otra o otras qualquier o qualesquier persona o personas, eglesias e monasterios e ospitales o çibdades o villa o lugar de mis regnos ayan e pretendan aver a la dicha villa e fortalesa e edifiçios della o a qualquier cosa o parte de lo que dicho es de que yo asy vos fago la dicha merçed, ora sea por título de mayoradgo commo por otra qualquier causa e rasón e título que sea o ser pueda, e sy la tal persona o personas, iglesia o monesterio o ospital o otra orden o religión o çibdad o villa o lugar algún derecho ayan a la dicha villa e fortalesa o sus términos e hedefiçios de la dicha villa e fortalesa o a qualquier cosa o parte dello o les pertenesçer pueden en qualquier manera que non ayan nin puedan aver recurso a la dicha villa e fortalesa nin a cosa alguna de lo que dicho es de que yo asy vos fago la dicha merçed saluo a mí e a mis herederos e subçesores, que mi merçed e voluntad es que vos ayades e vos quede entera e libre e desenbargada la dicha villa con su fortalesa e con todo lo sobredicho e qualquier cosa e parte de lo que dicho es, e que non vos pueda ser quitada nin seades vos nin los vuestros herederos e subçesores desapoderado dello nin de parte dello, cá mi merçed e deliberada voluntad es por las rasones e causas sobre dichas e en alguna emienda e satisfaçión de los dichos vuestros seruicios que son tales e tantos que desto e de mucho más vos soy encargado non vos sea nin pueda ser quitada nin cosa alguna de lo que dicho es, más que perpetuamente vos valga e sea firme e a los vuestros herederos e subçesores o aquél o aquellos que de vos e dellos ouieren causa commo dicho es, non enbargante qualquier ley de fuero e de ordenamiento e de partida o otra qualquier ley e derecho asy canónico commo çeuil escriptos e non escriptos o qualquier costunbre, estilo o fasanna que en contrario desto sea e ser pueda en qualquier manera, cá yo del dicho mi poderío real absoluto e çierta çiençia de que quiero vsar e vso en esta parte quanto a esto lo abrogo e derogo e anulo e alço e quito. E por esta mi carta o por su traslado signado de escriuano público mando al conçejo e alcaldes e alguasil e regidores ofiçiales e omes buenos e vesinos e moradores de la dicha villa e su tierra e a qualquier o quales quier dellos que vos ayan e reçiban por su sennor, e vos acaten e fagan la obediençia e reuerençia que deuen e son tenudos de faser commo a su sennor e cunplan vuestras cartas e mandamientos commo de sennor suyo, e vos den e fagan dar la posesión de la dicha villa e su tierra con su castillo e fortalesa e con todo lo que dicho es e cada cosa e cada cosa e parte dello, cá yo por esta mi carta e con ella vos do la dicha posesión e casi posesión de la dicha villa e de todo lo sobre dicho e cada cosa e parte dello, e desde aquí por la presente e con ella vos pongo e apodero envisto en todo ello e en qualquier cosa e parte dello, e es mi merçed e mando que por vos mesmo o por otro en vuestro nonbre la podades tener e poseer e tengades e poseades, non enbargante qualquier resistençia actual o verbal que en ella o en otra qualquier cosa de lo que dicho es falledes e vos reçibo e he por reçebido a ella. E otrosy por esta dicha mi carta o por 
su traslado signado commo dicho es mando al alcayde e tenedor o otra qualquier persona que por mí o en otra qualquier manera tiene el dicho castillo e fortalesa que vos lo dé e entregue o a vuestro çierto mandado, e vos acoja en lo alto e baxo dél e vos lo dexe libre e desenbargado con todas sus armas e pertrechos e bastimentos que con él reçibió e en el fallo e tiene, e que vos non pongan en ello escusa nin tardança alguna nin aspere sobre ello otra mi carta de mandamiento e segunda jusión, e dando vos lo e entregando vos lo o a vuestro çierto mandado commo dicho es yo por la presente o por el dicho su traslado le alço e quito qualquier pleyto e omenaje e juramento que él o ellos tengan fecho por el dicho castillo e fortalesa o por la guarda de la dicha villa e dó por libre e quito de todo ello a él e a su linaje para agora e para sienpre jamás.

E otrosy por esta dicha mi carta o por su traslado della signado de escriuano público mando al dicho príncipe don Enrique, mi muy caro e muy amado fijo e al maestre de Santiago mi condestable de Castilla e a los duques, condes, marqueses e ricos onbres, e a los otros maestres, priores de las órdenes, comendadores e subcomendadores, alcayde de los castillos e casas fuertes e llanas, e a todos los conçejos, corregidores e alcaldes, merinos e alguasiles, caualleros, escuderos, regidores, ofiçiales e omes buenos de todas e qualquier o quales quier çibdades e villas e lugares e otros qualesquier mis vasallos, súbditos e naturales de los dichos mis regnos e sennorios que vos defiendan e anparen con esta merçed que vos yo asy fago, e vos la non perturben nin consientan perturbar nin desapoderar de la posesión e sennorio de todo ello e de qualquier cosa e parte dello e a los dichos vuestros herederos e subçesores e a qualquier o qualesquier que de vos ouieren causa commo dicho es. E es mi merçed e por esta dicha mi carta o por su traslado signado commo dicho es mando e defiendo a los del mi consejo e a los mis oydores e alcaldes de la mi corte e chançellería e otros qualesquier mis jueses que se non entremetan de conosçer nin conoscan de qualquier pleyto o demanda que vos pongan o quieran poner sobre qual quier cosa o parte desta dicha merçed que vos yo asy fago, e si alguna o algunas personas dixieren aver a ello o a qualquier cosa o parte dello algún derecho o demanda que lo remitan ante mí e non conoscan dello. E otrosy mando al mi chançeller e a los otros mis ofiçiales que estan a la tabla de los mis sellos que vos den e fagan dar sobresto mi carta de preuillejo sellada con mi sello de plomo pendiente la más firme e bastante que menester vos sea e las otras mis cartas e sobrecartas que sobre ello menester ouierdes.

E los vnos nin los otros non fagan ende al por alguna manera sopena de la mi merçed e de confiscaçión de todos sus bienes e de los ofiçios e merçedes que ellos de mi tienen en qual quier manera para la mi cámara, e demás por qualquier o quales quier por quien fincar de lo asy faser e cunplir mando al ome que les esta mi carta mostrare o el dicho su traslado signado commo dicho es que los enplase que parescan ante mí en la mi corte do quier que yo sea del día que los emplasare fasta quinse dias primeros siguientes a desir por qual rasón non cunplen mi mandado, e mando sopena de priuaçión del ofiçio e de dies mill mrs. para la mi cámara a qual quier escriuano público que para esto fuere llamado que dé ende al que la mostrare testimonio signado con su signo porque yo sepa en commo se cunple mi mandado. E otrosy por esta dicha mi carta vos fago merçed commo dicho es e quiero que ayades para vos o para quien vos quisierdes todas e qualesquier debdas que al dicho conde dalua eran deuidas e le pertenesçian e avia de aver en qualquier manera en la dicha villa e su tierra e términos e jurediçión asy de los sobredichos e derechos commo de otras quales quier rentas e debdas en todo este presente anno de la data desta mi carta eçepto lo que por mi e por otros por mi mandado es tomado e resçibido. Dada en [en blanco] veynte dias de otubre anno del nasçimiento de nuestro sennor Jhesu Xripsto de mill e quatroçientos 
e quarenta e ocho annos. Yo el rey. E yo Pero Ferrándes de Lorca la fis escreuir por mandado de nuestro sennor el rey. Registrada.

1449, enero, 31. Almagro.

Trueque y cambio entre Enrique IV y Juan Pacheco de las villas de Chinchilla y el Castillo de Garci Muñoz por Medellín.

ADF, Caja 2, no 25

Conosçida cosa sea a quantos la presente carta de troque e canbio e promutaçión vieren commo yo don Enrique por la graçia de Dios prínçipe de Asturias, fijo primogénito heredero del muy alto e muy poderoso rey e sennor, mi sennor padre, el rey don Johán de Castilla e de León. Por quanto entre mi e vos don Johan Pacheco, marqués de Villena, mi mayordomo mayor, esta trabtado troque e cambio e pronuntaçión de la mi çibdad de Chinchilla con su castillo e fortalesa, e de la mi villa del Castillo de Garci Muñoz por la vuestra villa de Medellín e su tierra con su castillo e fortalesa e defesas e rentas, pechos e derechos della.

Por ende yo de mi libre e agradable voluntad entendiendo ser asy conplidero a mi seruiçio otorgo e conosco que do en troque e canbio e promutaçión por juro de heredad para syenpre jamás a vos el dicho don Johan Pacheco, marqués de Villena, mi mayordomo mayor, que estades presente la dicha mi çibdad de Chinchilla con su castillo e fortalesa, e la mi villa del Castillo de Garci Muñoz e sus aldeas e lugares con sus vasallos, sennorío e juridiçiones altas e baxas e mero mixto ynperio, e con todos sus términos e tierras e territorios e prados e pastos, montes, ríos, aguas corrientes estantes e manantes, e con todas las rentas, pechos e derechos, penas e calonnas e otras cosas al sennorío de las dichas çibdad e villas e de cada vna dellas e de sus tierras pertenesçientes e con todas sus entradas e salidas, vsos e pertenençias quantas han e deuen aver e les pertenesçen e pertenesçer deuen en qualquier manera e por qualquier rasón asy de fecho commo de derecho e vso e fueros e derechos, por la vuestra villa de Medellín, que es en el obispado de Plasençia, con su tierra e con su castillo e fortalesa e con todas sus pertenençias, que me vos dades en troque e cambio e promutaçión por la dicha mi çibdad de Chinchilla e villa del castillo de Garci Muñoz. Las quales dicha çibdad e villa con el dicho castillo e fortalesa, e con todo lo susodicho e declarado e con todo lo que yo hé e me pertenesçe e pertenesçer puede en qualquier manera, vos do en troque e cambio por la dicha vuestra villa de Medellin con su tierra e con el dicho su castillo e fortalesa para que sea vuestra e de vuestros herederos e suçesores asy vniversales commo syngulares e las ayades vos e ellos por juro de heredad para syenpre jamás para vender e enpennar, dar e donar, trocar e cambiar e enajenar e podades faser e fagades dellas e en ellas e en cada vna dellas todo lo que quesierdes e por buen touierdes commo de cosa vuestra propia libre e quita e dsenbargada. E por esta carta otorgo e conosco que la dicha vuestra villa de Medellin e su tierra con su castillo e fortalesa que me vos asy dades en troque e cambio e promutaçión vale tanto e más que las dichas çibdad de Chinchilla e villa del Castillo de Garci Muñoz que vos yo ansy do en troque por la dicha villa e que la dicha mi çibdad de Chinchilla con el dicho su castillo e la dicha villa del Castillo de Garci Muñoz con sus tierras e términos e con todo lo que dicho es que vos yo do e traspaso non vale más nin tanto auida compensaçión de vasallos e rentas e de rentas e vasallos, 
por quanto en la dicha çibdad e villa ay muy pocos derechos e rentas pertenesçientes al sennorio segund lo que yo en ellas he, e en la dicha villa de Medellín ay mucha más rentas asy de portadgos e defesas commo de otras rentas, por manera que vale mucho mas en renta la dicha villa de Medellín que la dicha mi çibdad de Chinchilla e la dicha villa del Castillo de Garçi Muñoz, pero sy más vale o puede valer en qualquier manera consyderando los muchos buenos e leales e sennalados seuiçios que vos auedes fecho al dicho rey mi sennor e a mí e en alguna emienda e remuneraçión dellos por la presente vos fago merçed, graçia e donaçión pura e perfecta e non reuocable que es dicha entre biuos syn condiçión alguna de la tal demasía sy la y ha o puede aver en alguna manera quier sea poca o mucha en grad cantidad o mayor o mucho mayor. E prometo por mi fe commo prinçipe fijo primogénito del dicho rey mi sennor e de mi pura e libre voluntad syn ningund enganno nin yndusimiento juro a Dios e a santa María e a esta sennal de crus corporalmente con mi mano tannida e a las palabras de los santos euangelios que por mi nin por otro en mi nombre nin de mis suçesores nin por otra persona alguna non yré nin verné nin consentiré yr nin venir contra este dicho troque e cambio, nin contra lo contenido en esta escriptura nin contra cosa nin parte dello nin por ninguna cabsa nin color nin rasón que sea nin ser pueda, antes lo guardaré e faré guardar e complir bien e verdaderamente e non pediré nin embiaré pedir nin impetrar absoluçión, relaxaçión nin comutaçión deste juramento nin de cosa dél al santo Padre nin a otra persona alguna que poderío aya nin por via de menor hedad nin de restituçión ni integrum nin por otro remedio nin de absilio nin de fecho nin de derecho, e puesto que me sea dada e otorgada de su propio motiuo e çierta çiençia e poderío absoluto o en otra qualquier manera non vsaré nin me aproucharé dél e que syenpre guardaré e compliré lo aquí contenido, e vos non será demandada la tal demasía en juisio nin fuera dél, e non allegaré exçebçión de dolo nin de fraude nin de enganno contra lo contenido en este contrabto e conosco que la non ovo nin ay, e renunçio que della non me pueda aprouechar quien diese cabsa a este contrabto quier interueniese en él, e me non llamaré menor de hedad nin reclamaré por que lo contenido en este contrabto nin cosa alguna dello sea desatado nin menoscabado, e syendo de todo çertificado de mi propia libre e agradable voluntad syn indusimiento alguno renunçio e parto de mí e de mi fauor e ayuda qualesquier leyes e derechos, fueros e ordenamientos, vsos e costunbres que en contrario desto ser o puedan ser, e asy mesmo las leyes que fablan en rasón delas donaçiones que deuen ser insinuadas, et otrosy la ley quel rey don Alfón de esclaresçida memoria onde yo vengo fiso e ordenó en las cortes de Alcalá de Henares en que se contiene que quando quier que alguno reçibe enganno en la venta o permutaçión en la meytad del justo preçio e dende arriba que puede ser descontado el tal enganno fasta quatro annos, e todas las leyes, fueros e derechos que fablan de las cabsas por donde las donaçiones pueden ser desatadas e reuocadas por desconosçimiento e desagradesçimiento o en otra qualquier forma e manera e quiero que me non vala nin dello me pueda aprouechar agora nin en algund tiempo. E por esta carta la qual vos do e entrego por posesión e casy posesión e del día de la data e otorgamiento della vos do e entrego las dichas mis çibdad de Chinchilla e villa del Castillo de Garçí Muños con su sennorío con todas sus tierras e términos e con el dicho Castillo e fortalesa e con todo lo susodicho e cada cosa e parte dello en troque en cambio e promutaçión por la dicha vuestra villa de Medellín, e çedo e trespaso en vos e en los dichos vuestros herederos e suçesores toda e qualquier abçión e derecho, propiedad e sennorío e posesión çeuill e natural, attual que yo tengo e me pertenesçe e pertenesçer puede asy de fecho commo de derecho en la dicha mi çibdad e villa con todo lo que dicho es, e me desapodero e desenvisto de todo ello e de cada cosa e parte dello e apodero e envisto en todo ello e cada cosa e parte dello a vos el dicho don Johán Pacheco, marqués de Villena, e vos do poder e 
abtoridad e facultad para que por vuestra propia abtoridad o de quien vuestro poder ouiere syn aver otro mandamiento nin liçençia del rey, mí sennor, ni mía nin de otro jues alguno podades entrar e tomar e aver por vuestras las dichas çibdad e villa e sus tierras e términos e jurediçiones e el dicho castillo de la dicha çibdad de Chinchilla con todo lo susodicho, e podades continuar e continuedes la posesión e casy posesión de todo ello e echar fuera a quien lo touiere e vos apoderar a toda vuestra voluntad syn pena e syn calumpnia alguna, non embargante que falledes ende qualquier restistençia abtual o verbal o otra qualquier. Et otorgo e me obligo de vos faser sanas, libres e desembargadas las dichas çibdad de Chinchilla e villa del Castillo de Garçí Muñoz con todas sus tierras e términos e con el castillo e fortalesa e con todo lo otro susodicho e qualquier cosa e parte dello, e de vos defender e anparar en el dicho sennorío tenençia e posesión con mi persona e casa e a mi sueldo, costa e misión de qualquier e qualesquier personas de qualquier estado o condiçión, preheminençia o dignidad que sean puesto que sean constituydas en dignidad real e desçendientes de stirpe o linaje de aquél o a mi conjuntas en qualquier debdo o grado que vos las demanden o embarguen o contrallen o perturben o molesten en juysio o fuera dél, asy de fecho commo de derecho, e de tomar e mandar tomar la bos del pleito e obtoría \{sic\} por vos e por vuestros herederos e suçesores a mis propias costas e misiones cada e quando por vos e por vuestros herederos e suçesores o quien vuestro poder o suyo ouiere fuere requerido en qualquier forma o estado quel pleito estouiere, sopena del valor de las dicha çibdad e villa con el doblo que quiero pagar vos por emienda e satisfaçión e en nombre de pena e interese conuençional que con vos pongo e la pena pagada o non que todavía nos faga sanas e libres e desembargadas las dichas çibdad e villa e castillo e fortalesa con todo lo susodicho e qualquier cosa e parte dello que vos fuere contrariado so obligaçión de todos mis bienes asy fiscales commo patrimoniales que expresamente para ello obligo.

E por esta carta mando a los conçejos, alcaldes, alguasiles, regidores, caualleros, escuderos, ofiçiales e ommes buenos de la dicha mi çibdad de Chinchilla e villa del Castillo de Garçi Muñoz e de cada vna dellas que vos ayan e reçiban por su sennor e de las dichas çibdad e villa e de cada vna dellas, e vos obedescan e acaten e presten la reuerençia e obediençia que deuen commo a su sennor, e cumplan vuestras cartas e mandamientos, e vos recudan e fagan recudir con todas las rentas, pechos e derechos pertenesçientes al sennorio de la dicha çibdad e villa e de cada vna dellas. E otrosy mando al alcayde que por mí o por otra qualquier persona tiene el dicho castillo e fortalesa de la dicha mi çibdad de Chinchilla que vos dé e entregue a vos o a quien vuestro poder ouiere el dicho castillo e fortalesa della e vos apodere en lo alto e baxo dél a toda vuestra voluntad, e fasiéndolo asy yo por la presente le alço e quito vna e dos e tres veses qualquier pleito e omenaje o juramento o fidelidad que a mí o a otra qualquier persona tenga fecho por el dicho castillo e fortalesa, e quiero que non aya nin incurra en penas algunas nin le pueda ser notada infamia alguna e le do por libre e quito de todo ello para syenpre jamás.

E yo, el dicho don Johan Pacheco, marqués de Villena, otorgo e conosco que do e otorgo a vos el muy alto e muy poderoso mi sennor el prínçipe don Enrique que estades presente la dicha mi villa de Medellín con el dicho castillo e fortalesa della, e con todas sus pertenençias e vsos e fueros e derechos e costumbres, e con la justiçia çeuill e criminal alta e baxa e mero misto inperio e destrito territorio e rentas e pechos e derechos con todo lo que en ella e en su tierra e términos a mí pertenesçe e pertenesçer deue en qualquier manera e por qualquier rasón. De la qual dicha villa de Medellín e su tierra con su castillo e fortalesa ante de agora vos yo ove dado la posesión, la qual teniades en troque e cambio e permutaçión por las dichas çibdad de Chinchilla con su castillo e fortalesa e por la dicha villa del Castillo de Garci Muñoz 
para que sea vuestra e de vuestros herederos e suçesores e la podades enajenar e faser della e en ella lo que vuestra sennoría quesiere e mandare commo de cosa vuestra propia, libre e quita e desenbargada. E conosco e otorgo que la dicha villa de Medellín e su castillo e fortalesa que a vos el dicho prínçipe, mi sennor, yo do en troque e cambio puesto que vala más que la dicha çibdad de Chinchilla e villa del Castillo de Garçi Muñoz, en qualquier manera reconosçiendo las muchas merçedes, graçias e benefiçios por vuestra altesa a mí fechos yo vos do en seruiçio e fago pura donaçión de la demasía della quier sea poca o mucha, e prometo e otorgo que por mí nin por otro en mi nombre nunca vos sea demandada la tal demasía en juysio nin fuera dél, nin allegare ende exçebçión de fraude nin de enganno e conosco que lo non ovo nin ay, e renunçio la ley que da remedio a los que son engannados en la meytad del justo preçio e dende arriba, que me non vala nin pueda valer nin pueda della aprouechar en juysio nin fuera dél. E desde oy día en adelante que esta carta es fecha e otorgada me desapodero e desenvisto a mí e a mis herederos presentes e futuros de la dicha villa de Medellín e castillo e fortalesa della e del sennorio e derecho e tenençia e posesión e propiedad della, e apodero e envisto a vos el dicho prínçipe, mi sennor, en todo ello e vos do poder conplido para que vuestra altesa o quien vuestro poder ouiere la tome e mande tomar e apoderar della e del castillo e fortalesa della commo de cosa vuestra propia syn otro consentimiento nin liçençia de otro jues alguno non embargante qualquier resistençia abtual o verbal que ende fuese o sea fecha por mí o por otra persona alguna. La qual dicha villa con todo lo susodicho que vos asy do en troque e cambio otorgo e me obligo de vos sanear e faser sana e çierta de qualquier que la demande a vuestra altesa en juysio o fuera dél, e sy lo tal acaesçiere o naçiere que yo e mis bienes e mis herederos seamos e quiero ser tenudo al saneamiento de la dicha villa con todo lo suso dicho e que saliré abtor e tomaré la bos del pleito cada e quando fuere requerido por vos el dicho prínçipe, mi sennor, o por vuestros herederos e suçesores o por quien vuestro poder o suyo ouiere en qualquier forma e estado que estouiere el tal pleito, sopena del valor de la dicha villa de Medellín con el doblo que quiero pagar vos por emienda e satisfaçión e en nombre de pena e interese conuencional que con vuestra merçed pongo, e la pena pagada o non que todavía sea tenudo a la riedra e saneamiento dello so obligación de todos mis bienes muebles e rayses que expresamente para ello obligo. E por esta carta mando al concejo, alcaldes, alguasil, regidores, caualleros, escuderos, oficiales, e ommes buenos de la dicha villa de Medellín que ayan e reçiban por sennor de la dicha villa a vos el dicho prínçipe, mi sennor, e vos recudan e fagan recudir con todas las rentas, pechos e derechos pertenesçientes al sennorio de la dicha villa, e otrosy mando al alcayde de la dicha villa que por mi tiene el castillo e fortalesa de la dicha villa de Medellín que lo dé e entregue a vos el dicho prínçipe, mi sennor, o a quien vuestro poder ouiere, e apodere en él a vos e a vuestro çierto mandado en lo alto e baxo dél a toda vuestra voluntad, cá él fesiéndolo asi yo por esta carta le alço e quito vna e dos e tres veses qualquier pleito e omenaje que me tiene fecho por el dicho castillo e fortalesa e le dó por libre e quito de todo ello para siempre jamás. E sobre esto que dicho es e cada cosa e parte dello renunçio e parto de mí e de mi ayuda todo derecho escripto e non escripto, ordinario e establesçido, e todo absilio e remedio de derecho e toda exçebçión de enganno e todo otro benefiçio de restituçión in integrum e todo otro remedio de derecho de que me podiese anparar e defender en juysio e fuera dél para poder contradesir esta carta e todo lo en ella contenido e quiero que me non vala.

E yo el sobredicho prínçipe don Enrique e otrosy yo el dicho don Juan Pacheco, marqués de Villena, e cada vno de nos damos poder conplido a quales quier jueses o justiçias ante quien esta carta paresçiere e fuere pedida esecuçión a la juridiçión de los quales nos sometemos con postura que la non podamos declinar antes 
ni después del pleito contestado que por todos los remedios del derecho nos apremie e compellen a tener e guardar e complir todo lo contenido en este contrabto e cada cosa e parte dello, e sy lo non veniéremos e compliéremos segund e por la forma e manera que en él se contiene que fagan entrega e esecuçión en nuestros bienes e en cada vno e qualquier de nos, asi por el prinçipal commo por las penas sy en ellas cayéremos, e syn nos más llamar nin oyr nin çitar tomen tantos de nuestros bienes muebles e rayses doquier que los fallaren e los vendan en pública almoneda syn plaso alguno de terçero día nin de nueue días nin de treynta días e syn otro plaso de fuero nin derecho nin de costumbre, e de los mrs. que valieren fagan pago a la parte que pediere esecuçión del dicho contrabto asy del prinçipal commo de las dichas penas e de las costas que sobre ello se recresçieren. E para mayor validación de lo contenido en este dicho contrabto de troque e permutaçión, yo el dicho prínçipe don Enrique e yo el dicho don Juan Pacheco, marqués de Villena, e cada vno de nos renunçiamos las leyes e fueros e derechos que disen que ninguno non se entienda renunçiar el derecho que non sabe que le pertenesçe, e otrosy la ley e derecho que dise que el enganno que es por venir que non pueda ser renunçiado, e otrosy la ley que dise que quando el enganno da cabsa al contrabto de promutaçión quel tal contrabto es ninguno de derecho, e la ley que dise que los derechos proybitiuos e que dan çierta forma non pueden ser renunçiados, e la ley que dise que fasta çierto tiempo deue ser fecha la denunçiaçión para que aquél que es obligado a euiçión deue tomar la bos del pleito, e la ley que dise que el que se somete a jurediçión agena que la pueda declinar ante del pleito contestado, e la ley que dise que primeramente deue ser fecha esecuçión en los bienes muebles que en los rayses, e el derecho que da çierta orden en la subastaçión e vençión de los bienes, e la ley que dise que general renunçiaçión non vala nin obre tanto commo la espeçial e otrosy todas las otras leyes, fueros e derechos e vsos e costumbres escriptos e non escriptos, generales e espeçiales que son o podrían ser contra lo contenido en este contrabto de promutaciçon para lo quebrantar o menguar en todo o en parte alguna.

E desto otorgamos dos cartas públicas, amas en vn tenor tal la vna commo la otra para cada vno de nos la suya. E yo el dicho prínçipe quiero e me plase e yo el dicho marqués otorgo e consiento que cada vna de las dichas dos cartas que paresçiere que fuere presentada asy en juysio commo fuera del fagan tanta fe e tan complida proeua commo si amas paresçiesen e fuesen presentadas, las quales yo el sobre dicho prínçipe mandé e rogué e yo el dicho marqués rogué a Alfonso Gonçáles de la Hoz, secretario del dicho rey, nuestro sennor, e su notario público en la su corte e en todos los sus regnos, e secretario de mí el dicho prínçipe, que fesiese o mandase faser e las sygnase de su sygno, e para mayor firmesa yo el dicho prínçipe firmelas de mi nombre e mandelas sellar con mi sello. Que fueron fechas e otorgadas en la villa de Almagro treynta e vn dias de enero, anno del nasçimiento del nuestro sennor Jhesucristo de mill e quatroçientos e quarenta e nueue annos. Yo el Prínçipe. Testigos que fueron presentes quando el dicho sennor prínçipe e el dicho marqués de Villena otorgaron lo suso dicho e juraron de lo guardar e complir Alfonso Vasques, canónigo en la iglesia de Segouia, capellán del sennor prínçipe e Diego Arias e Ruy Gonsales, secretarios del dicho sennor prínçipe. Va emendado en la segunda plana o dis del Castillo.

Yo Alfonso Gonsáles de la Hos, secretario de nuestro sennor el rey e su escriuano de cámara e notario público en la su corte e en todos los sus regnos e secretario del dicho sennor prínçipe fuy presente quando el dicho sennor prínçipe e el dicho don Johan Pacheco, marqués de Villena, otorgaron lo suso dicho e por ruego e mandamiento suyo fis escreuir esta escriptura en tres fojas de papel çeuty e más esta 
plana, la qual escriptura es para el dicho marqués de Villena, e fis aquí este mio signo en testimonio. Alfonso Gonçales.

1451.

Enrique IV concede a Juan Pacheco la villa de las Peñas de San Pedro.

$\mathrm{ADF}$, Caja $31, \mathrm{n}^{0} 7$.

Don Enrique, por la gracia de Dios, prínçipe de Asturias, fijo primogénito heredero del muy alto e esclaresçido prínçipe e muy poderoso rey e sennor, mi sennor, el rey don Johan de Castilla e de León. Por faser bien e merçed a vos don Johan Pacheco, marqués de Villena, mi mayordomo mayor e del mi consejo, por los muchos e buenos e leales e sennalados seruiçios que me auedes fecho e fasedes de cada día e en alguna remuneraçión dellos fago vos merçed e graçia e donaçión pura perpetua e non reuocable que es dicha entre biuos de la mi villa de las Pennas de Sant Pedro que es çerca [en blanco] con todos sus términos e montes e prados e pastos e dehesas e exidos e aguas corrientes e estantes, e con toda su jurediçión e justiçia ceuil e criminal e mero misto ynperio, e con todos sus vasallos e pechos e rentas e fueros e derechos e tributos e martiniegas e portadgos e yantares e escreuanías e diesmos e almoxarifadgos, e con todas las otras cosas a la dicha villa e al sennorío della pertenesçientes para que ayades e tengades todo lo susodicho e cada cosa dello por vuestro e commo vuestro para vos e para vos e para vuestros herederos e subçesores e para quien vos quesiéredes e por bien touiéredes por juro de heredad para syenpre jamás, e para que lo podades vender, donar, trocar, cambiar e enajenas e faser dello e en ello e en cada cosa e parte dello asy commo de cosa vuestra propia, libre e quita e desenbargada. E desde agora parto e quito e renunçio de mi e de mis herederos e subçesores la tenençia e posesion velcasy e propiedad e sennorio e casy sennorio de la dicha villa de las Pennas de Sant Pedro e de todo lo suso dicho e de cada cosa e parte dello e lo çedo e traspaso a vos e en vos el dicho don Johan Pacheco, marqués de Villena, por esta carta e por la tradiçión della que en vos fago e vos apodero en todo ello e en cada cosa e parte dello bien e perfeta e conplidamente, e a mayor abondamiento me constituyo e otorgo desde agora por tenedor e poseedor de la dicha villa e de todo lo suso dicho e de cada cosa e parte dello por vos e en vuestro nombre e para vos en qualquier manera que yo u otro o otros por mí de aquí adelante lo tengamos e poseamos, e allende desto vos do liçençia, poder e abtoridad por esta presente carta para que por vos mesmo o por otro o otros en vuestro nombre podades entrar e tomar e aprehender la tenençia e posesión velcasy e propiedad e sennorio real e actual de la dicha villa e de todo lo susodicho e de cada cosa dello, avnque vos sea fecha cerca dello qualquier resystençia actual o verbal con armas o syn armas por mí o por otro o otros en mi nombre o por el dicho conçejo e ommes buenos de la dicha villa o por otras qualesquier personas o comunidades o vniuersidades e avnque sobrello se leuanten o teman leuantar qualesquier escándalos o bolliçios, cá yo desde agora vos entrego la tenençia e posesión velcasy propiedad e sennorio e casy sennorío de todo ello e de cada cosa e parte dello commo dicho es. De la qual dicha villa con todo lo susodicho vos fago la dicha merçed e graçia e donaçión asy commo de cosa mía e por mí poseyda e prometo e me obligo de vos la faser sana e de pas e de vos defender e anparar en la tenençia e posesión e propiedad e senorío della a vos e a los 
dichos vuestros herederos e subçesores e aquél o aquellos que de vos o dellos ouieren cabsa contra todas e qualesquier personas e vniuersidades e comunidades que vos embargaren o contrariaren o perturbaren o molestaren por vias de fecho o de derecho en la tenençia e posesión velcasi e propiedad e sennorío e casy sennorío de la dicha villa e de todo lo susodicho o de qualquier cosa o parte dello a ella o al sennorío della pertenesçiente en qualquier manera e por qualquier rasón, e vos sacar a pas e a saluo e syn dapnno e syn costa alguna de todo ello en tal manera que lo vos tengades e poseades e los dichos vuestros herederos e subçesores después de vos aquél o aquellos que de vos o dellos ouieren causa libre o desenbargada e paçificamente e syn perturbaçión nin molestaçión alguna. E prometo otrosy de non reuocar nin vos quitar esta dicha merçed e graçia e donaçión que vos yo fago de la dicha villa e de todo lo susodicho e cada cosa e parte dello por ninguna causa nin rason que sea o ser pueda, avnque se diga que vos el dicho marqués de Villena me fuestes desagradesçido o desconosçido o que cometistes alguno de los casos o cavsas porque de derecho se pueden reuocar las donaçiones, nin porque diga que esta dicha merçed e donaçión es fecha contra las leyes e ordenanças del dicho rey, mi sennor, o de los reyes sus anteçesores o contra sus cartas o mandamientos nin por otra rasón alguna, cá yo de mi çierta çiençia e deliberada voluntad quiero que syn embargo de todo lo susodicho sea firme, estable e valedera esta dicha merçed e graçia e donaçión que vos yo fago por syenpre jamás, e que se non pueda reuocar en manera alguna nin por alguna cabsa nin rasón que sea o ser pueda, la qual prometo por mi fe asy commo fijo primogénito heredero del dicho rey, mi sennor, de tener e guardar por syenpre jamás, e pido por merçed al dicho rey, mi sennor, que la aprueue e confirme e retefique e sy conplidero vos fuere vos faga merçed de nueuo de todo ello e de cada cosa e parte dello supliendo qualesquier defectos e dispensando con qualesquier derechos e leyes e ordenanças que contra esto sean o ser puedan. E mando al conçejo, alcaldes, regidores, caualleros, escuderos, ofiçiales e ommes buenos de la dicha villa de las Pennas de Sant Pedro que vos resçiban e ayan de aquí adelante por sennor de la dicha villa e de todo lo susodicho e de cada cosa e parte dello, e vos entreguen las llaues e puertas de la dicha villa e de las fortalesas della e vayan a vuestros llamamientos e enplasamientos e cunplan vuestros mandamientos e vos recudan e fagan recudir con todos los pechos, rentas, fueros e derechos e tributos e martiniega e yantares e portadgos e escriuanías e diesmos e almoxerifadgos e otras qualesquier cosas a la dicha villa e al sennorio della e de su tierra pertenesçientes en guisa que vos non mengue ende cosa alguna, lo qual e cada cosa dello mando que fagan e cumplan non embargantes qualesquier pleitos e omenajes e juramentos e fidelidades e seguridades e otras qualesquier cosas que por la dicha villa e por todo lo susodicho o por qualquier cosa o parte dello me tengan fechos en qualquier manera, e los do por libres e por quitos de todo ello a ellos e a sus linajes e bienes ellos fasiendo e cumpliendo lo susodicho e apoderando a vos el dicho marqués de Villena o a quien vuestro poder ouiere en la dicha villa commo dicho es. E los vnos nin los otros non fagan ende al por alguna manera sopena de la mi merçed e de priuaçión de los dichos sus ofiçios e de confiscaçión de todos sus bienes de los que asy non fisieren e cumplieren para la mi cámara, de los quales dichos bienes e ofiçios yo por esta mi carta fago merçed e donaçión a vos el dicho marqués de Villena e vos do poder para que los podades entrar e tomar por vos o otro o otros en vuestro nombre por vuestra propia abtoridad en tal caso syn ynteruenir otra mi liçençia nin mandamiento nin de otro jues alguno e sin preçeder sentençia nin comisión alguna çerca dello, e demás mando al omme que les esta mi carta mostrare que los enplase que parescan ante mí do quier que yo sea el dicho conçejo por su procurador e las personas syngulares de la dicha villa personalmente del día que los enplasare fasta quinse días primeros syguientes a desir por qual rasón non cumplen mi 
mandado. E mando so la dicha pena a qualquier escriuano público que para esto fuere llamado que dé ende al que les esta mi carta mostrare testimonio sygnado con su sygno porque yo sepa en cómo se cumple mi mandado.

Dada en [en blanco] dias de [en blanco] anno del nasçimiento de nuestro sennor Xhesu Xripsto de mill e quatroçientos e çinquenta e vn annos.

1452, noviembre, 15. Valladolid.

Trueque y cambio de Iniesta por Castrojeriz.

ADF, Catálogo Antiguo, Leg. 42, $n^{\circ} 4$.

Las cosas que son apuntadas e capituladas entre nos don Juan Pacheco, marqués de Villena, e Ruy Días de Mendoça, mayordomo del rey, nuestro sennor, sobre los troques e cambios e ygualanças que se han de faser de la villa de Castroxeris, que es de mí el dicho marqués, e de la villa de Yniesta, que es de mí el dicho Ruy Días, son las siguientes

Primeramente

Que yo el dicho don Juan Pacheco, marqués, he de dar e dó en troque e cambio a vos el dicho Ruy Dias de dicha mi villa de Castroxeris con su castillo e fortalesa e con toda su tierra e término e alcaldía e juridiçión e merindades e sennorío, jurisdiçión ceuil e criminal alta e baxa e mero misto ynperio, e con todos sus vasallos e aguas corrientes manantes e estantes, e con todas sus rentas e pechos e derechos e con todo lo otro poco o mucho al sennorío de la dicha villa e su tierra anexo e conexo deuido e pertenesçiente en qualquier manera, segund e por la vía e forma e manera que yo oy día la tenga e poseo e me pertenesçe. Lo qual todo vos he de dar en el dicho troque e canbio a vos el dicho Ruy Dias por la vuestra villa e castillo de Yniesta e con todos sus términos e vasallos e rentas e pechos e derechos e otras cosas al sennorío de la dicha villa anexos e pertenesçientes. E yo el dicho Ruy Dias he de dar e dó a vos el dicho marqués por la dicha vuestra villa de Castroxeris con todo lo susodicho en el dicho troque e cambio la dicha mi villa de Yniesta con su castillo e fortalesa e con todos sus términos e vasallos e aguas manantes e estantes, rentas, pechos e derechos e sennorío e juridiçión ceuil e criminal alta e baxa e mero misto ynperio e con todo lo otro poco o mucho al sennorío de la dicha villa anexo e pertenesçiente. E desto amas las dichas partes avemos de otorgar vn contracto fuerte e firme ante escriuano e notario público.

Otrosy somos acordados que los títulos e posesiones que cada vno de nos otros tiene de cada vna de las sobredichas villas que cada vno de nos otros dé e entregue el suyo al otro y el otro al otro, al tienpo que se entregaren a mí el dicho marqués la dicha villa de Yniesta e a mí el dicho Ruy Dias la dicha villa de Castroxeris con sus castillos e fortalesas, las quales seremos tenudos e obligados de entregar e faser entregar realmente, yo el dicho marqués la dicha villa de Castroxeris con su castillo e fortalesa e con toda su juridiçión e sennorío quanto yo oy día hé e auer puedo e me pertenesçe en qualquier manera a vos el dicho Ruy Dias, e yo el dicho Ruy Dias a vos el dicho marqués la dicha villa de Yniesta con su castillo e fortalesa e con todas las otras cosas que yo en ella he e poseo e me pertenesçe en qualquier manera desde oy día de la fecha deste otorgamiento destos capítulos fasta veynte días primeros seguientes. 
Otrosy, que nos los dichos marqués de Villena e Ruy Dias de Mendoça juremos los contractos del dicho troque e venta.

Otrosy, por quanto se presume que en alguna de las dichas villas e sus tierras e juridiçión ay más vasallos e rentas sobre vasallos e pechos ordinarios e rentas de alcaldías e merindades e juridiçiones sobre vasallos e otras rentas, heredades, molinos, e otras ventajas más en la vna villa que en la otra, e que todo sea visto e numerado por Juan de Soto e Diego de Proaño, contando el vasallo con juridiçión a quatro mill mrs. e el millar sobre vasallos en veynte e çinco mill mrs., e asimismo apresçiando e estimando e moderando la dicha juridiçión sobre vasallos e las otras rentas e heredades e molinos e otras vantajas susodichas e declaradas, e non se ygualando estos dos en las cosas susodichas que tomen por terçero al sennor Pedro de Cunna, guarda mayor del rey, nuestro sennor, e que sy este terçero con qualquier dellos ygualare e moderare non se podiendo ellos ygualar que vala lo quel vno dellos con el terçero determinare e seremos tenudos a lo complir segund por ellos fue tasado e aquí es capitulado.

Otrosy, por quanto en qualquier de los dichos logares avrá deudas que serán deuidas a qualquier de nos o a qualquier persona de nuestras casas con bastimientos e prouisiones e pertrechos que estos mesmos Juan de Soto e Diego de Proaño los puedan tasar e ygualar porque se pague a las partes que las ouiere de aver.

Otrosy, por quanto yo el dicho Ruy Dias tengo quarenta e vn mill mrs. de juro de heredat situados en la villa de Requena, los quales segund el tracto e juramiento que entre nos es por causa del dicho troque, yo el dicho marqués he de aver e dar por ellos otros tantos mrs. de juro de heredat a vos el dicho Ruy Dias situados en las villas e lugares de la dicha merindat de Castroxeris, tanto que non sean situados en el cuerpo e rentas de la dicha villa de Castro e su tierra, que sean de la mesma calidat de los dichos mrs. de juro de la dicha Requena que yo el dicho marqués he de reçibir de vos el dicho Ruy Dias, o que sea tenudo de dar a vos el dicho Ruy Dias su equiualençia en dineros segúnd valieren, e estos mrs. se renunçiarán al término en que mandaren los dichos Juan de Soto e Diego de Proaño faser las pagas de las otras cosas e se darán asentado en los libros del dicho sennor rey al dicho término.

Otrosy, que non sean contados en el dicho troque de las dichas villas por las vna parte nin por la otra mrs. algunos de los que pertenesçen a las rentas del dicho sennor rey, saluo lo que pertenesçe ordinariamente a los dichos lugares e a los sennores dellos.

Otrosy, que todo lo que restare contando vasallos e mrs. sobre vasallos e todas las otras cosas segund que ante desto estaua apuntado e capitulado los preçios que vale, los dichos sennores jurarán e farán omenaje de pasar por lo que en esta parte fisieren e ordenaren los dichos Juan de Soto y Diego de Proaño, e en lo que se desacordaren que lo declare el vno con el dicho terçero.

Otrosy, que los sennores prínçipe e marqués e maestre de Calatrava jurarán e farán omenaje e lo darán firmado de su nonbre e sellado con sus sellos de nunca ser nin consentyr en tornar la dicha villa de Castroxeris a don Diego Gómes de Sandoual, conde de Castro, nin a sus herederos nin a otra persona nin personas que digan que tienen título por rasón del dicho conde o por qualquier otra persona, antes que serán en la anparar e defender al dicho Ruy Dias e a sus herederos en la posesión della e de todo lo al sennorío pertenesçiente que para ello sea nesçesario, asy por sus personas commo con sus gentes e a su costa e misión. Este mesmo juramento han de faser al dicho Ruy Dias los dichos sennores de le ayudar a defender qualquier otra villa o heredamiento que le sea dado de los dichos caualleros cuyos bienes están secrestados e ocupados por el dicho sennor rey, e de le procurar con el dicho sennor rey o en otra 
qualquier manera sus fechos e acreçentamiento de estado commo los suyos mesmos, e este juramento se dará firmado e sellado de oy a veynte días primeros siguientes.

Otrosy, yo el dicho Ruy Dias fago pleito e omenaje de nunca ser nin consentyr que sea tornado al rey de Nauarra nin a los otros caualleros ninguna cosa de lo que agora tienen e touieren de aquí adelante los sennores prínçipe e marqués e maestre, e que en esta parte se juntará con los dichos sennores prínçipe e marqués e maestre con su persona e casa e gentes en defensa de todo lo que dicho es.

Otrosy, que si algunos mrs.son tomados asy de pedidos commo de monedas e alcaualas e terçias por los dichos marqués e Ruy Dias o por otras personas por su mandado en las dichas villas o qualquier dellas, que los dichos sennores sean tenudos e obligados de dar saneamiento a los conçejos de las dichas villas de las tales tomas, por tal guisa que a los dichos conçejos les sean reçebidos en cuenta e les non venga danno, lo qual sean obligados a lesdar fasta el día de Nabidat primera siguiente.

Otrosy, que en el cuento de los vasallos que se han de contar en cada vna de las dichas villas que non sea contado por parte de ninguno de nos los clérigos pues que non son de nuestra jurediçión, e asy mesmo que los escuderos e fidalgos que se cuenten dos de los tales fidalgos e escuderos por vn pechero.

Fueron fechos e otorgados e jurados e fincados estos dichos capitolos en la noble villa de Valladolid quinse dias de nouiembre anno del nasçimiento del nuestro sennor Jhesu Xrispto de mill e quatroçientos e çinquenta e dos annos.

El marqués. Ruy Dias. Le acompañan dos sellos de cera.

Testigos que fueron presentes a todo lo susodicho e vieron aquí firmar sus nombres a los dichos sennores marqués de Villena e Ruy Dias de Mendoça, don Martin de Gusmán e Enrique de Figueredo, guarda del sennor prínçipe, e el bachiller Ruy Gutierres, alcalde en la corte e chancellería del dicho sennor rey.

E yo Juan Ferrándes de Hermosilla, escriuano de cámara de nuestro sennor el rey e su notario público en la su corte e en todos los sus regnos e sennorios e secretario del dicho sennor prínçipe, fuy presente a esto que dicho es en vno con los dichos testigos, e por ruego e otorgamiento de los dichos sennores marqués e Ruy Dias estos capítulos fis escreuir e en mi presençia e de los dichos testigos los firmaron de sus nombres, los quales van escriptos en tres fojas de pliego de papel çebtí con esta en que va mi sygno, e por ende fis aquí este mio signo a tal en testimonio. Juan Ferrándes.

E yo Gonçalo Ferrándes de Toro, escreuano de cámara de nuestro sennor el rey e su notario público en la su corte e en todos los sus regnos e sennorios, fuy presente a todo lo aquí contenido en vno con los dichos testigos, e por ruego e otorgamiento de los dichos sennores marqués de Villena e Ruy Dias de Mendoça esta escriptura escreuí, la qual los dichos sennores en mi presençia e de los dichos testigos firmaron de sus nombres, la qual va escripta en tres fojas de pliego de papel çeuty con esta en que va mi signo, e por ende fis aquí este mio signo a tal en testimonio. Gonçalo Ferrándes.

Fecha de recepción del artículo: febrero 2006.

Fecha de aceptación y versión final: abril 2007. 